\title{
Silk-Based Antimicrobial Polymers as a New Platform to Design Drug-Free Materials to Impede Microbial Infections
}

\author{
Albina R. Franco, Erica Palma Kimmerling, Carla Silva, Fernando J. Rodrigues, \\ Isabel B. Leonor, * Rui L. Reis, * and David L. Kaplan
}

Surgical site infections (SSI) represent a serious health problem that occur after invasive surgery, thus new antimicrobial biomaterials able to prevent SSI are needed. Silks are natural biopolymers with excellent biocompatibility, low immunogenicity and controllable biodegradability. Spider silk-based materials can be bioengineered and functionalized with specific peptides, such as antimicrobial peptides, creating innovative polymers. Herein, we explored new drug-free multifunctional silk films with antimicrobial properties, specifically tailored to hamper microbial infections. Different spider silk domains derived from the dragline sequence of the spider Nephila clavipes 6 mer and 15mer, 27 and $41 \mathrm{kDa}$ proteins, respectively) were fused with the two antimicrobial peptides, Hepcidin (Hep) and Human Neutrophil peptide 1 (HNP1). The self-assembly features of the spider silk domains ( $\beta$-sheets) were maintained after functionalization. The bioengineered 6 mer-HNP1 protein demonstrated inhibitory effects against microbial pathogens. Silk-based films with $6 \mathrm{mer}$ HNP1 and different contents of silk fibroin (SF) significantly reduced bacterial adhesion and biofilm formation, whereas higher bacterial counts were found on the films prepared with 6mer or SF alone. The silk-based films showed no cytotoxic effects on human foreskin fibroblasts. The positive cellular response, together with structural and antimicrobial properties, highlight the potential of these multifunctional silk-based films as new materials for preventing SSI.

\section{Introduction}

Surgical site infections (SSI) are one of the most serious complications after post-transplant and surgery, accounting for $20 \%$ of all healthcare-associated infections each year. Despite recent improvements in healthcare, namely the use of broad spectrum antibiotics and the improvement of surgical techniques, ${ }^{[1,2]}$ SSI continues to persist, posing an alarming threat to public health worldwide. ${ }^{[3,4]}$ In addition, the economic burden of patient hospital care is also significant. ${ }^{[4]}$ Healthcare-associated infection costs related to SSI have been estimated to be on average $€ 325$ per day in Europe and \$25 546 per infection in the United States. ${ }^{[4-6]}$ The recurrent use of antibiotic therapeutic to treat microbial infections has led to the increase in microbial strain resistance, and thus, reducing antibiotic treatment efficacy. ${ }^{[3]}$ One of the causes that contribute to the development of SSI could be the contamination during surgery or contamination of the medical devices even prior to implantation. The surfaces of medical devices can harbor pathogens, thus serving as a reservoir for infections. ${ }^{[7]}$ The adherence of bacterial and the subsequent formation of biofilms on such devices occurs by the same process as the adhesive mechanism that facilitates host cell adherence, proliferation, and growth. ${ }^{[8]}$

Current strategies to prevent SSI rely mostly on the local administration of antibiotics or antibacterial agents to the implant site. ${ }^{[9,10]}$ The incorporation of antibiotics on fibers or as coatings in medical devices, like surgical sutures, help prevent
Dr. A. R. Franco, Dr. C. Silva ${ }^{[+]}$, Dr. I. B. Leonor, Prof. R. L. Reis

3B's Research Group, I3Bs - Research Institute on Biomaterials, Biodegradables and Biomimetics

University of Minho, Headquarters of the European Institute of Excellence on Tissue Engineering and Regenerative Medicine,

AvePark, Parque de Ciência e Tecnologia, Zona Industrial da Gandra 4805-017 Barco, Guimarães, Portugal

E-mail: belinha@i3bs.uminho.pt; rgreis@i3bs.uminho.pt

Dr. A. R. Franco, Dr. C. Silva, Prof. F. J. Rodrigues, Dr. I. B. Leonor,

Prof. R. L. Reis

ICVS/3B's - PT Government Associate Laboratory

4805 Braga/Guimarães, Portugal

The ORCID identification number(s) for the author(s) of this article can be found under https://doi.org/10.1002/mabi.201800262.
Prof. F. J. Rodrigues

Life and Health Sciences Research Institute, School of Health Sciences University of Minho

4805 Braga, Portugal

Prof. R. L. Reis

The Discoveries Centre for Regenerative and Precision Medicine Headquarters at University of Minho

Avepark 4805-017 Barco, Guimarães, Portugal

Dr. E. Palma Kimmerling, Prof. D. L. Kaplan

Department of Biomedical Engineering

Tufts University

Medford, MA 02155, USA

${ }^{[+]}$Present address: CEB- Centro de Engenharia Biológica, Universidade do Minho, Campus de Gualtar 4710-057 Braga Portugal Braga, Portugal

DOI: 10.1002/mabi.201800262 
the adherence and formation of microbial biofilms. ${ }^{[11,12]}$ However, this approach may have a negative effect by increasing microbial resistance to antibiotics, ultimately failing to prevent SSI. There is a need to focus research on alternatives to antibiotics, by pursuing new antimicrobial agents with high efficiency and less opportunity to develop bacterial resistance. ${ }^{[13]}$ For instance, various types of antimicrobial polymeric coatings have been explored, such as polycationic polymers, ${ }^{[14]}$ silver ions, ${ }^{[15]}$ and antimicrobial peptides ${ }^{[8]}$ among others. Therefore, it is important to develop new biomaterials that are capable of preventing and controlling microbial proliferation on medical devices, and subsequently the formation of biofilms, without impairing wound healing, the proliferation of host cells, or encouraging microbial resistance.

The exploitation of novel polymers as anti-infective agents has progressively become a primary source of biomaterials. Natural polymers, such as spider silk and SF, among others, are already widely used for different medical applications. ${ }^{[16,17]}$ Spider silk stands out as a unique class of structural proteins ${ }^{[18]}$ due to its excellent biocompatibility, low immunogenicity, toughness, and ductility. ${ }^{[19,20]}$ Among the different types of spider silk, the major ampullate dragline silk from Nephila clavipes is one of the most extensively studied silks due to the mechanical properties. ${ }^{[18]}$ Similarly, SF is commonly used as a biomaterial due to its biocompatibility, biodegradability, mechanical properties, water vapor permeability, and minimal inflammatory response. ${ }^{[12,21]}$

Over the last decade, spider silk-based biomaterials were engineered and designed through recombinant DNA technology to suit different medical applications. ${ }^{[22]}$ Microbial cells factories, and especially Escherichia coli endotoxin-free cultures, are versatile protein factories. They are easy to use as well as their cultivation is cost-effective, to support the scale-up production of recombinant proteins. ${ }^{[23,24]}$ With the aid of genetic and protein engineering, novel tailored-made strategies can be designed to suit user or process requirements. ${ }^{[25]}$ Through this technique, new recombinant proteins with enhanced features can be synthesized while retaining the outstanding properties of the native spider silk. ${ }^{[26]}$ For instance, genetically engineered spider silk proteins with biological domains to promote cell adhesion and proliferation, ${ }^{[27]}$ formation of vascular tissue, ${ }^{[28]}$ or bone regeneration ${ }^{[29,30]}$ have been reported. Similarly, spider silk proteins functionalized with antimicrobial peptides were also designed to reduce or control biomaterial-associated infections. ${ }^{[19]}$ In this previous work, the fusion of specific human antimicrobial peptides including human neutrophil defensin 2 (HNP-2), human neutrophil defensin 4 (HNP-4), and hepcidin (Hep) with a spider silk domain demonstrated bactericidal activity against Gram- and Gram+ bacteria. By further investigating these fusion proteins, multifunctional polymers can be envisaged as new drug-free biomaterials targeting a reduction in SSI.

The aim of this study was to investigate the potential of bioengineered spider silk proteins functionalized with antimicrobial peptides as drug-free films to prevent SSI. To achieve this goal, multifunctional, composite material, silk-based films were prepared by combining bioengineered spider silk proteins with SF extracted from Bombyx mori cocoons. Herein, spider silk domains derived from the dragline sequence of the spider Nephila clavipes (6mer and 15mer) were fused with two antimicrobial peptides, Hep and Human Neutrophil peptide 1 (HNP1), through cloning. The recombinant proteins were expressed, and their secondary structure as well as assembly and antimicrobial activity were evaluated. The bioengineered protein that demonstrated the best antimicrobial activity against well-known pathogens was used to study multifunctional silk-based films with different percentages of SF. Bacterial adhesion and the formation of biofilms on the multifunctional silk-based films were determined, as well as cytotoxicity. With this new approach, we envisage that these new silk-based films can serve as a platform to engineer drug-free polymers for preventing SSI.

\section{Experimental Section}

\subsection{Bioengineered Spider Silk Proteins Functionalized with Antimicrobial Peptides}

\subsubsection{Expression and Purification of Bioengineered Spider Silk Proteins Functionalized with Antimicrobial Peptides}

The antimicrobial peptides, Hep, and HNP1 were individually inserted in pET30 vectors already carrying either six $(6$ mer; $27 \mathrm{kDa})$ or fifteen $(15 \mathrm{mer} ; 41 \mathrm{kDa})$ repeats of the consensus sequence motifs derived from the major ampullate dragline silk I protein from Nephila clavipes (MaSp1; Accession number P19837). ${ }^{[31]}$ Also, these spider silk blocks copolymers (6mer or $15 \mathrm{mer}$ ) carried six histidine residues to facilitate protein purification, and two restriction sites, SpeI and NheI, flanking the edges for sub cloning of functional domains. ${ }^{[31]}$ The cDNA sequence of the genes corresponding to the antimicrobial peptides of interest was selected based on the consensus motif derived from the back translation of Hep (Accession number P18172) and HNP-1 (Accession number P59665) proteins. Consensus sequences were obtained from the UniProt (http://www.uniprot.org/). The inserts, Hep and HNP1, were prepared through annealing of synthetic single strand oligonucleotides sequences. The oligonucleotides Hep-top, Hep-bot, HNP1-top, and HNP1-bot were chemically synthesized with 5'phosphorolated ends (Invitrogen). At the flanking edge of each oligonucleotide sequence, the restriction sites for NheI and SpeI were also included to facilitate the insertion of the oligonucleotide sequences into the pET30L vector, already containing the spider silk block of interest (6mer or $15 \mathrm{mer}$ ). The annealing reactions containing a 20 pmol $\mu \mathrm{L}^{-1}$ oligonucleotide solution were carried by decreasing the temperature from 95 to $20{ }^{\circ} \mathrm{C}$ with a gradient of $0.1{ }^{\circ} \mathrm{C} \mathrm{s}^{-1}$, and its presence was confirmed on $8 \%$ agarose gels.

Before the insertion of the different cDNA sequences (Hep or HNP1) into pET30L, the vectors containing either 6mer or 15mer silk blocks were first digested with SpeI (New England Biolab), and dephosphorylated with calf intestinal phosphatase (CIP; New England Biolab) to prevent the re-circulation of the vector. The vector linearization was confirmed on a $0.8 \%$ agarose gels and the linear vectors were further purified using the QIAquick gel extraction kit (Qiagen, CA, USA, 28706). The 
cDNA sequences of Hep and HNP-1 were ligated individually to the different silk coding block (6mer and 15mer) present in vector pET30L using T4 DNA ligase enzyme (New England Biolabs) overnight at $16^{\circ} \mathrm{C}$.

Competent cells E. coli DH5 $\alpha$ (Invitrogen) were transformed with the new ligation products (vector pET30L carrying 6mer, 6mer-Hep, 6mer-HNP1, 15mer, 15mer+ Hep, 15mer+HPN-1). Transformants were spread onto LB agar plates with $50 \mu \mathrm{g} \mathrm{mL} \mathrm{m}^{-1}$ kanamycin, and incubated overnight at $37{ }^{\circ} \mathrm{C}$, for positive selection of the successful transformants. The successful insertion of Hep or HNP-1 in the silk block vectors was confirmed by DNA sequencing, using T7 and T7 term primers. The bioengineered proteins were expressed in E. coli BL21De3 strain (Invitrogen). Overnight bacterial colonies previously grown $37^{\circ} \mathrm{C}$ in $100 \mathrm{~mL}$ LB sup-

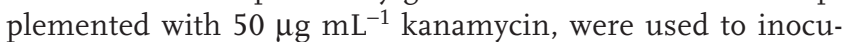
late 1 L of HyperBoth (0107; Athens Enzyme Systems Protein Expression) supplemented with $50 \mu \mathrm{g} \mathrm{mL} \mathrm{m}^{-1}$ kanamycin, and grown at $37^{\circ} \mathrm{C}$ with $250 \mathrm{rpm}$ agitation, until an OD600 of 0.7-0.9 was reached. Protein expression was induced by adding isopropyl $\beta$-D-thiogalactoside (IPTG) at a final concentration of $1 \mathrm{~mm}$ for $4 \mathrm{~h}$, and centrifuged at $8000 \mathrm{rpm}$ for $20 \mathrm{~min}$ at $4{ }^{\circ} \mathrm{C}$. The cell pellet was stored at $-20{ }^{\circ} \mathrm{C}$ overnight. Then, cell pellet was thawed in ice for $30 \mathrm{~min}$, resuspended overnight in denaturating buffer $\left(100 \mathrm{~mm} \mathrm{NaH}{ }_{2} \mathrm{PO}_{4}, 10 \mathrm{~mm}\right.$ Tris $\mathrm{HCl}, 8 \mathrm{~m}$ Urea, $\mathrm{pH} 8.0$ ) at $4{ }^{\circ} \mathrm{C}$, and the lysate supernatant was recovered by centrifugation at $8500 \mathrm{rpm}$ for $30 \mathrm{~min}$ at $4{ }^{\circ} \mathrm{C}$. A $50 \%$ Ni-NTA slurry in a ratio $1: 4$ (Ni-NTA:lysate) was added to the lysate, and mixed gently overnight at $4{ }^{\circ} \mathrm{C}$. The supernatant/Ni-NTA resin mixture was added onto a glass Econo-column (Biorad). The mixture was washed four

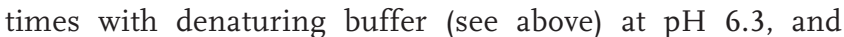
eluted with denaturating buffer at $\mathrm{pH} 5.8$ and 4.5. Wash flowthrough and eluted fractions were analyzed by SDS-PAGE to confirm protein purification.

The purified proteins were dialyzed into cellulose ester snake skin membranes with a 100-500 Da molecular weight cutting off (Spectra/Por Biotech, 131054), for one day, with $100 \mathrm{~mm}$ sodium phosphate buffer ( $\mathrm{pH}$ 5.5), to keep a steady $\mathrm{pH}$ and avoid protein precipitation. Extensive dialysis against water was followed for three days to remove salts. Finally, the dialyzed proteins were lyophilized.

The expression levels and molecular weight of the new chimeric proteins were assessed by SDS-PAGE and Westernblot, using a Bis-Tris 4-12\% gel (NuPAge, Invitrogen). Gels were stained using Commassie blue staining for band detection. Western-Blot, bands from the SDS-PAGE were electrotransferred onto a nitrocellulose membrane at $30 \mathrm{~V}$ for $16 \mathrm{~h}$. Membranes were blocked for $1 \mathrm{~h}$ at $4{ }^{\circ} \mathrm{C}$ with a blocking solution (3\% BSA or $5 \%$ Milk in TBS buffer). Then, the membrane was washed with TBS buffer and incubated for $1 \mathrm{~h}$ with mouse anti-histidine monoclonal antibody (1:100-1:3000 diluted in blocking solution). Membranes were again washed three times for $5 \mathrm{~min}$ with agitation with TBS buffer with Tween $20(1 \mathrm{~mL}$ $\left.\mathrm{L}^{-1} \mathrm{TBS}\right)$, and incubated for $1 \mathrm{~h}$ with goat anti mousse IgG AP antibody (1:5000 dilution in blocking solution) with agitation. Bands were detected in the membrane using a solution of 5-bromo-4-chloro-3-indolylphosphate (BCIP) and nitrobluetetrazolium (NBT).

\subsubsection{Bioengineered Protein Secondary Structure}

The secondary structure of bioengineered proteins was performed by attenuated total reflection Fourier transform infrared spectroscopy (ATR-FTIR; IR Prestige-21 spectrometer Shimadzu, Japan). The proteins 6mer-Hep, 6mer-HNP1, 15mer-Hep, 15mer-HNP1, 6mer, and 15mer were dissolved in ultrapure water to a final concentration of $2 \%(\mathrm{w} / \mathrm{v})$. Then, $50 \mu \mathrm{L}$ of each protein solution was cast onto a nonadherent polydimethylsiloxane surface and left to dry at room temperature. The protein films were treated with $90 \%$ methanol treatment for $2 \mathrm{~h}$ to induce the transition of secondary structure from random coil to $\beta$-sheet. The spectra of the chimeric protein films were acquired in the absorbance mode in the range of $4000-400 \mathrm{~cm}^{-1}$ by averaging 100 individual scans per chimeric protein film at a resolution of $8 \mathrm{~cm}^{-1}$. The quantification of the secondary structure was based on the analysis of the amide I and amide II regions $\left(1700-1450 \mathrm{~cm}^{-1}\right)$. The quantification of the secondary structure was based on the analysis of the amide I and amide II regions $\left(1700-1450 \mathrm{~cm}^{-1}\right)$. Collected spectra were linear baseline corrected, normalized, and subsequently deconvoluted by fitting with a Lorentzian function using PeakFit software (Systat Software Inc., California, USA). The average percentage for the secondary structures, mainly $\beta$-sheet, random-coil $/ \alpha$-helix, and turns were calculated through the integration of the area of each deconvoluted peak curve, normalizing the obtained value to the total area of the amide I and amide II regions. ${ }^{[32]}$ The secondary structure of the chimeric proteins was also analyzed by circular dichroism (CD - Model J1500, JASCO, Japan) spectroscopy. The spectra were collected between 190 and $260 \mathrm{~nm}$ with a step size of $1 \mathrm{~nm}$, an averaging time of $1 \mathrm{~s}$ and five scans were collected for each sample. A baseline spectrum was subtracted from the samples. A sample cell with a $0.1 \mathrm{~cm}$ path length was used. Measurements were performed in triplicate with 1 and $0.5 \mathrm{mg} \mathrm{mL}^{-1}$ protein solution in phosphate buffer ( $\mathrm{pH}$ 7.4).

\subsubsection{Antimicrobial Activity of the Bioengineered Proteins}

Radial diffusion assay: The antimicrobial activity of the bioengineered proteins was evaluated against different well-known wound infecting pathogens, such as, Gram-negative bacteria (Pseudomonas aeruginosa, Escherichia coli), Gram-positive bacteria (Methicillin resistant $S$. aureus-MRSA, Vancomycin resistant S. aureus-VRSA, Enterococcus feacalis, Bacillus pumillus), and a fungus (Candida albicans). The Kirby-Bauer method was chosen but it was adapted from the original method for testing microbial resistance to antibiotic drugs. Microbial cultures were grown in Luria-Bertani (LB) broth medium at $37^{\circ} \mathrm{C}$ overnight. Cells were centrifuged at $9000 \mathrm{rpm}$ for $5 \mathrm{~min}$ at $4{ }^{\circ} \mathrm{C}$, and then, the cell pellet was washed twice with sterile phosphate buffered saline solution (PBS; pH 7.4). The cell pellet was re-suspended in sterile PBS ( $\mathrm{pH} 7.4)$, adjusted to an optical density of $0.3(\lambda=$ $610 \mathrm{~nm}$ ) and spread onto Muller Hinton Agar (Oxoid, UK) with a sterile swab. Blank sterile disks (Oxoid, UK) were impregnated with $30 \mu \mathrm{L}$ of different concentrations of the bioengineered proteins $\left(10,50,100\right.$, and $\left.200 \mu \mathrm{g} \mathrm{mL} \mathrm{m}^{-1}\right)$ and placed on top of the inoculated agar and incubated overnight at $37^{\circ} \mathrm{C}$. Experiments 
were carried out in triplicates. Negative controls using either antibiotic impregnated disks (Vancomycin; Oxoid, UK) or PBS were also used. The diameter of the zone formed around the disks was measured to calculate the area of growth inhibition.

Bacterial viability in liquid media: further anain another factor of the bioengineered proteins on the microbial pathogens described above were also assessed in LB medium. Microbial cultures were grown overnight as mentioned earlier and centrifuged at $9000 \mathrm{rpm}$ for $5 \mathrm{~min}$ at $4{ }^{\circ} \mathrm{C}$. The cell pellets were suspended in sterile PBS (pH 7.4), and adjusted to an optical density of $0.1(\lambda=610 \mathrm{~nm})$. Then $50 \mu \mathrm{L}$ of sterile solution of the bioengineered proteins at different concentration $(10,50,100$, and $200 \mu \mathrm{g} \mathrm{mL}-1$ ) were added to $50 \mu \mathrm{L}$ of microbial solution and incubated at $37^{\circ} \mathrm{C}$ for $24 \mathrm{~h}$ with agitation (150 rpm). Bacterial growth was monitored by Optical density (OD $600 \mathrm{~nm}$ ). Each experiment was performed in triplicate.

\section{1.4. Aggregation and Zeta Potential of the Bioengineered Proteins}

The assembly of 6mer-Hep, 6mer-HNP1, 15mer-Hep, 15merHNP1, 6mer, and 15mer spider silk proteins was determined by dynamic light scattering (DLS) measurements using a Zetasizer NanoZS instrument (ZEN3600, MALVERN Instruments, Worcestershire, UK). Different concentrations of each bioengineered protein were prepared $(10,50,100$, and $200 \mu \mathrm{g} \mathrm{mL}-1$ ) in ultrapure water. Scattering data was collected at a $173^{\circ}$ scattering angle. Three measurements were made per protein. The charge of each bioengineered protein sample was also determined by zeta potential measurements over the same range of protein concentrations, in triplicate.

\subsection{Multifunctional Silk-Based Films}

\subsubsection{Silk Fibroin Extraction and Assembly of the Multifunctional Silk-Based Films}

The multifunctional silk-based films were fabricated by combining lyophilized (SF) and the bioengineered proteins 6 mer and 6mer-HNP1. SF was extracted from raw cocoons of $B$. mori supplied from the Portuguese Association of Parents and Friends of Mentally Disabled Citizens (APPACDM, Castelo Branco, Portugal) according to the procedure previously described. ${ }^{[33]}$ Briefly, clean B. mori cocoons were cut into $1 \mathrm{~cm}$ pieces and boiled in $0.02 \mathrm{M}$ sodium carbonate solution for $20 \mathrm{~min}$ at $0.25 \%(\mathrm{w} / \mathrm{v})$ to remove sericin. Afterward, the degummed SF fibers were washed with deionized water for $20 \mathrm{~min}$ three times and dried in a fume hood overnight. The dried SF fibers were solubilized with a $9.3 \mathrm{~m}$ aqueous lithium bromide solution at $60{ }^{\circ} \mathrm{C}$ for $1 \mathrm{~h}$. The solubilized SF were dialyzed against deionized water for three days using a $3500 \mathrm{~g} \mathrm{~mol}^{-1}$ MWCO dialysis cassettes, until lithium bromide was completely removed. After dialysis, the aqueous SF solution was centrifuged twice at $8700 \mathrm{rpm}$ at $5{ }^{\circ} \mathrm{C}$ for $25 \mathrm{~min}$ and decanted into a new tube to remove insoluble particulates. SF was lyophilized and kept at room temperature, until further use. The multifunctional films were prepared by combining $2 \%(\mathrm{w} / \mathrm{v})$ of the bioengineered spider silk proteins 6 mer-HNP1 or 6 mers in HFIP (Sigma) with different contents of SF, $10 \%, 12 \%$, or $15 \%$, (w/v) by gentle mixing into solution prior to casting. Also, control films were prepared with only $10 \%, 12 \%$, or $15 \% \mathrm{SF}$ and used as controls, since they did not have any bioengineered spider silk protein. Films were prepared by casting a $100 \mu \mathrm{L}$ aliquot of the silk-based HFIP protein solution onto a $10 \mathrm{~mm}$ microplate coated with PDMS and air dried for $24 \mathrm{~h}$.

\subsubsection{Secondary Structure of the Silk-Based Films}

The secondary structure of the multifunctional silk-based films was assessed by ATR-FTIR, as previously described. The characterization was performed before and after annealing with $90 \%$ methanol for $2 \mathrm{~h}$, analyzing amide I and amide II regions $\left(1700\right.$ to $\left.1450 \mathrm{~cm}^{-1}\right)$. The baseline of the silk-based films spectra were corrected and normalized before peaks fit deconvolution with the Lorentzian function in PeakFit, as described in above.

\subsubsection{Scanning electron microscopy (SEM) of the silk-based films}

The morphological characterization of the multifunctional silkbased films was by SEM (JSM-6010LV, JEOL, Japan). Prior to SEM observations, the silk-based films were coated with platinum by ion sputtering (EM ACE600, Leica, Germany).

\subsubsection{Atomic Force Microscopy (AFM) of the Silk-Based Films}

The AFM measurements were conducted on a Bruker AFM (Dimension Icon) with NanoScope Analysis software v1.5 (Bruker). The surface topography of the silk-based films $(5 \times$ $5 \mu^{2}$ ) was performed in PeakForce Tapping (ScanAsyst) in air with silicon nitride cantilevers (ScanAsyst-Air, Bruker) with spring constant of $0.4 \mathrm{~N} \mathrm{~m}^{-1}$ and frequency of $70 \mathrm{kHz}$. The roughness measurements were analyzed with NanoScope Analysis software v1.5 where the root-mean-square (Rms) and the arithmetic average height $\left(R_{\mathrm{a}}\right)$ of the films were measured. Rms indicates the standard deviation of the height values within a specific area, and determines the surface roughness. ${ }^{[34,35]} R_{\mathrm{a}}$ is a commonly used roughness parameter, defined as the average deviation of the roughness irregularities from the mean line over the sampling length. ${ }^{[34,35]}$

\subsubsection{Bacteria Viability and Adherence on the Silk-Based Films}

Prior to the bacterial tests, the silk-based films were previously sterilized by immersion in a $70 \%$ ethanol solution for $2 \mathrm{~h}$, washed three times with sterile PBS (pH 7.4) and dried overnight. The viability of bacteria grown on the surface of the silk-based films was assessed against Methicillin resistant $S$. aureus (MRSA). Before seeding, all films were hydrated in PBS (pH 7.4). Then, films were incubated with $200 \mu \mathrm{L}$ of bacteria inoculum, previously adjusted to an optical density of $0.1(\lambda=$ $610 \mathrm{~nm}$ ) at $37{ }^{\circ} \mathrm{C}$ with agitation (150 rpm) for $24 \mathrm{~h}$. Afterward, the films were washed three times with PBS and stained with $200 \mu \mathrm{L}$ solution of a Live/Dead Bacterial Viability Kit (Molecular 
probes, L7007, Invitrogen) for $15 \mathrm{~min}$ at room temperature. After staining, the films were washed three times with sterile PBS (pH 7.4) to remove excess fluorescence dye. Live bacteria were stained green using SYTO 9 and Dead bacteria were stained red using PI and visualized using a Fluorescence Microscope (Imager Z1m, Zeiss), under 40× magnification. For each film type, four random images were acquired using a digital camera (AxioCam MRm5, Zeiss). ImageJ (NIH, Maryland, USA) was used for all image processing. Bacterial viability was calculated as the ratio of the live to dead bacteria. SEM was used to evaluate MRSA adherence and biofilm formation on the surface of the silk-based films after $24 \mathrm{~h}$ growth at $37^{\circ} \mathrm{C}$ in Luria-Bertani broth (LB) medium. After incubation, silk-based films were removed from the LB medium and washed twice with sterile PBS (pH 7.4). Films were fixed with $4 \%$ glutaraldehyde for $60 \mathrm{~min}$ in the dark at room temperature. Then, films were dehydrated in a series of ethanol-water solutions $(20 \%$, $40 \%, 50 \%, 70 \%, 90 \%, 100 \%, v / v)$, and left to dry overnight prior to coat with palladium by ion sputtering.

\subsubsection{Cytotoxicity Assay}

The biological impact of the silk-based films on human foreskin fibroblasts (HFF) was assessed. HFFs are an immortalized cell line and (American Type Culture Collection) the silk-based films were sterilized as described in Section 2.5. Prior to cell seeding, cells were cultured in Dulbecco's modified Eagle's medium (DMEM) supplemented with 10\% (v/v) fetal bovine serum, 1\% penicillin streptomycin (v/v) at $37{ }^{\circ} \mathrm{C}$ with $5 \% \mathrm{CO}_{2}$ in a humidified environment. When confluence was reached, cells were trypsinized $(0.25 \%$ trypsin/EDTA solution) from the culture flask. Sterile silk-based films were cultured in a 24-well plate with $100 \mu \mathrm{L}$ of a cell suspension containing 40000 cells and incubated for $4 \mathrm{~h}$ at $37^{\circ} \mathrm{C}$ with $5 \% \mathrm{CO}_{2}$ in a humidified environment. Afterward, $900 \mu \mathrm{L}$ of DMEM was added to each well and incubated for 1 and 3 days under the same conditions as described above. Cells cultured onto tissue culture polystyrene (TCPS) with standard culture medium were used as a negative control. Cell growth and adherence were evaluated after 1 and 3 days of incubation, respectively, using phase contrast light microscopy (Leica).

Cell proliferation was evaluated by dsDNA picogreen quantification (P11495, Invitrogen), according to the manufacturer's instructions. After each incubation time, DMEM medium was removed from each well and the cells were washed twice with sterile PBS ( $\mathrm{pH}$ 7.4). Then, $1 \mathrm{~mL}$ of ultrapure water was added to each well to induce complete membrane lysis, incubated at $37^{\circ} \mathrm{C}$ for $1 \mathrm{~h}$ and stored at $-80^{\circ} \mathrm{C}$ until further analysis. After thawing, samples were analyzed for DNA content and measured at an excitation wavelength of $485 / 20 \mathrm{~nm}$ and at an emission wavelength of 528/20 nm. DNA content was calculated according to a standard curve. Samples without cells were used as control.

HFF metabolic activity was determined by Alamar Blue assay (DAL1100, Invitrogen) according to the manufacture instructions. After each culture time, DMEM medium was removed from each well and the cells were washed twice with sterile PBS (pH 7.4). Then, $1000 \mu \mathrm{L}$ of Alamar Blue solution (1/10 in DMEM; v/v) was added directly to each well and incubated for $4 \mathrm{~h}$ at $37{ }^{\circ} \mathrm{C}$ with $5 \% \mathrm{CO}_{2}$. The metabolic activity was recorded by fluorescence at an excitation wavelength of $570 \mathrm{~nm}$ and emission at $585 \mathrm{~nm}$, and normalized by DNA content to account for variation in cell number. The experiments were run in triplicate.

\subsection{Statistical Analysis}

All the quantitative results were obtained from triplicate samples. Data are reported as mean \pm standard deviation and tested for normality. For statistical analysis, a one-way ANOVA test was performed using GraphPad Prism 6.0 software and the differences were considered statistically significant if $p<0.05$.

\section{Results and Discussion}

\subsection{Characterization of Bioengineered Spider Silk Proteins Fused with Antimicrobial Peptides}

One of the major characteristics of biomaterials with anti-infective properties is related to the need to prevent the adherence of microbial pathogens and the formation of biofilms. ${ }^{[8,36]} \mathrm{New}$ bioengineered spider silk proteins with antimicrobial properties offer an advantage, since they are specifically tailored to prevent SSI, while also avoiding systemic exposure to antibiotics. However, the full potential for this approach needs to be further investigated.

Through recombinant DNA technology, new bioengineered spider silk proteins 6mer-HNP1, 15mer-Hep, and 15merHNP1 were successfully produced (Figure 1). The expression and purification of the chimeric proteins 6mer, 15mer, 6merhepcidin, 6mer-HNP-1, 15mer-Hepcidin, and 15mer-HNP-1 was assessed with SDS-PAGE (Figure 1A) and Western blots (Figure 1B). The molecular weights of the chimeric proteins 6mer, 6mer+hepcidin, 6mer-HNP-1, 15mer, 15mer-hepcidin, and 15mer-HNP-1 were 27, 29, 29, 41, 44, and $44 \mathrm{kDa}$, respectively (Figure 1C).

The ATR-FTIR spectra of the 6mer, 6mer-Hep, 6mer-HNP1, 15 mer, 15 mer-Hep, and 15mer-HNP1 protein films were measured before and after methanol treatment, and exhibited strong amide I (1700-1600 $\left.\mathrm{cm}^{-1}\right)$ and amide II (1600-1500 $\mathrm{cm}^{-1}$ ) regions (Figure 2A). Before methanol treatment, the spectra for the chimeric proteins films with antimicrobial peptides (6mer-Hep, 6mer-HNP1, 15mer-Hep, and 15mer-HNP1) exhibited vibrational modes in the range of $1650-1647 \mathrm{~cm}^{-1}$, of the amide I region, which indicated helix/random coil conformations. After methanol treatment, these peaks appeared in the range of $1620-1630 \mathrm{~cm}^{-1}$, in the amide I region, and in the range of $1510-1530 \mathrm{~cm}^{-1}$, in the amide II region, indicative of antiparallel $\beta$-sheet structures (Figure 2A), confirming the structural transition of the protein to the aqueous-stable features. ${ }^{[19,37]}$ Also, the spectral deconvolution of the bioengineered proteins was made (Figure 2B,C). After methanol treatment, antiparallel $\beta$-sheet content increased whereas a decrease in $\alpha$-helix/random coil conformation was observed in the bioengineered proteins with the 6 mer or 15 mer spider silk domains (Figure 2B,C). The $\beta$-sheet content in the protein films after methanol treatment in the 6 mer domains was $40.5 \%$ for 6 mer, $49.8 \%$ for 6 mer-Hep, $46.4 \%$ 6mer-HNP1, whereas in 
A

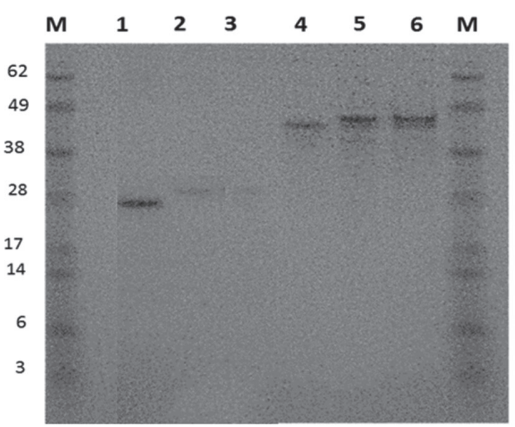

B
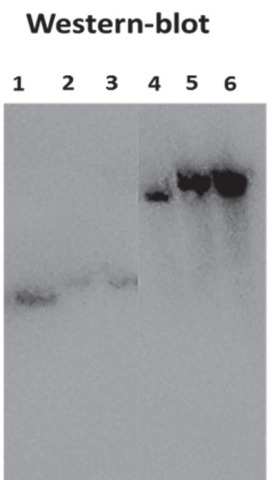

C

\begin{tabular}{|c|c|c|}
\hline Construct name & Sequence & MW (kDa) \\
\hline $6 \mathrm{mer}$ & HHHHHH( $\underline{\text { (SGRGGLGGQGAGAAAAAGGAGQGGYGGLGSQGT) }}{ }_{6}$ & 27 \\
\hline 6mer-Hep & HHHHHH(SGRGGLGGQGAGAAAAAGGAGQGGYGGLGSQGT) $)_{6}$ DTHFPICIFCCGCCHRSKCGMCCKT & 29 \\
\hline 6mer-HNP1 & HHHHHH( $\left(\underline{\text { SGRGGLGGQGAGAAAAAGGAGQGGYGGLGSQGT) }}{ }_{6}\right.$ ACYCRIPACIAGERRYGTCIYQGRLWAFCC & 29 \\
\hline $15 \mathrm{mer}$ & 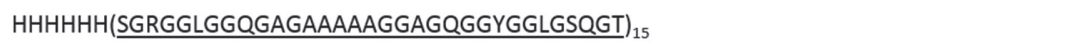 & 41 \\
\hline 15mer-Hep & 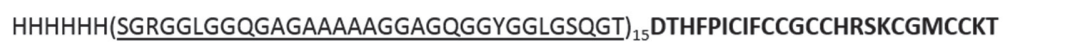 & 44 \\
\hline 15mer-HNP1 & HHHHHH( $(\underline{\text { SGRGGLGGQGAGAAAAAGGAGQGGYGGLGSQGT) }})_{15}$ ACYCRIPACIAGERRYGTCIYQGRLWAFCC & 44 \\
\hline
\end{tabular}

Figure 1. a) SDS-PAGE gel stained with colloidal blue and b) Western-blot using anti-histidine antibody. Legend: M: Lambda DNA/HindIII Marker (ThermoFisher); 1: 6mer; 2: 6mer-Hep; 3: 6mer-HNP1, 4: 15mer; 5: 15mer-Hep; 6: 15mer-HNP1. c) Amino acid sequence of the bioengineered spider silk proteins.

A

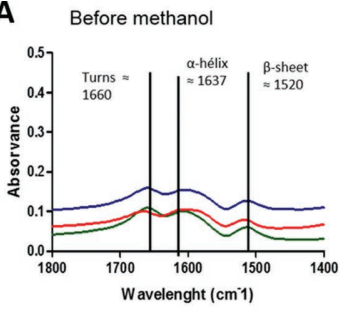

Before methanol

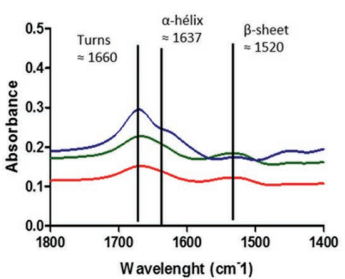

After methanol

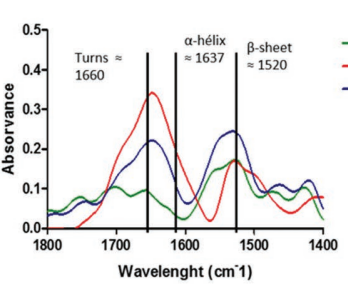

After methanol

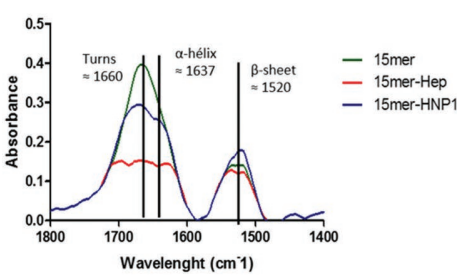

B
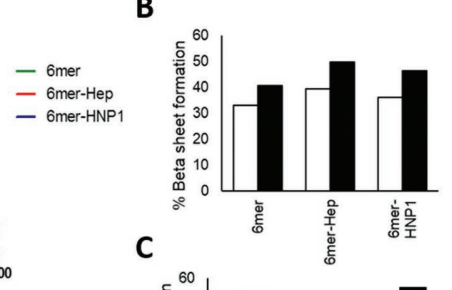

C
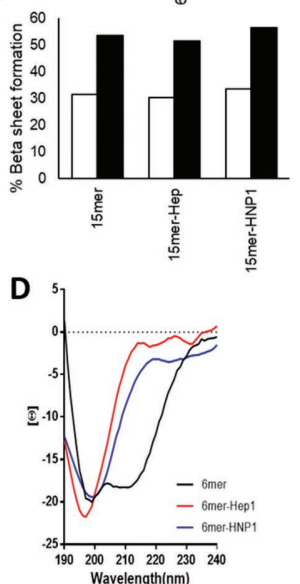
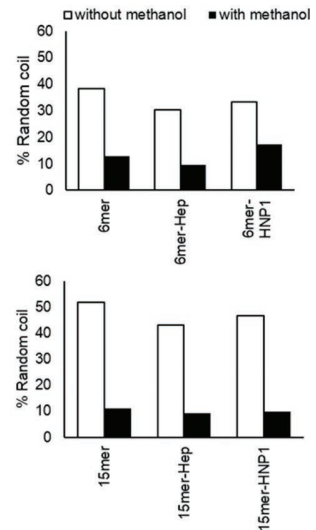

E

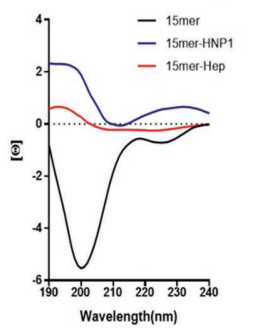

Figure 2. Characterization of the bioengineered proteins. A) ATR-FTIR spectra of the bioengineered spider silk proteins before and after methanol treatment; B) Percentage of $\beta$-sheet and random coil/helix conformations after spectra deconvolution of 6 mer, 6 mer-Hep and $6 \mathrm{mer-HNP1}$ proteins; C) Percentage of $\beta$-sheet and random coil/helix conformations after spectra deconvolution of 15 mer, 15 mer-Hep, and $15 \mathrm{mer}-\mathrm{HNP1}$ proteins; D) CD spectra of the bioengineered spider silk proteins 6 mer, 6 mer-Hep and 6mer-HNP1 in phosphate buffer (pH 7.4); E) CD spectra of the bioengineered spider silk proteins $15 \mathrm{mer}, 15 \mathrm{mer}-\mathrm{Hep}$, and $15 \mathrm{mer}-\mathrm{HNP1}$ in phosphate buffer ( $\mathrm{pH} 7.4)$. 
the 15 mer domains were $53.4 \%$ for 15 mer, $51.3 \%$ for 15 merHep, and $56.4 \%$ for 15 mer-HNP1. The higher $\beta$-sheet conformations after methanol treatment promoted structure stability and water insolubility demonstrate that the core self-assembling of the spider motif maintained the formation of $\beta$-sheet crystals in the new bioengineered proteins. ${ }^{[19,31]}$ Results demonstrate that the spider silk domains, 6 mer, and 15 mer were able to keep their self-assembly features after functionalization with the antimicrobial peptides. Regarding the bioengineered proteins with antimicrobial peptides, the values of $\beta$-sheet content were similar to the ones obtained in the $6 \mathrm{mer}$ and $15 \mathrm{mer}$ controls, suggesting that the addition of the antimicrobial peptides had no influence on structural conformation of the new bioengineered proteins after methanol treatment.

The CD spectra of the bioengineered proteins, 6mer, 6merHep, 6mer-HNP1, 15mer, 15mer-Hep, and 15mer-HNP1 were obtained in phosphate buffer ( $\mathrm{pH} 7.4$ ) (Figure 2D,E). In the case of 6 mer, a predominant $\beta$ and $\alpha$ conformation was observed, with two minima at 198-205 and $215 \mathrm{~nm}$ (Figure 2D). The 6mer-Hep and 6mer-HNP1 proteins showed a negative ellipticity, with a minimum of 195-200 nm (Figure 2D). These results for assembly and secondary structure are consistent with previous studies. ${ }^{[19,38]}$ The presence of a $\beta$-conformation in the 6 mers proteins suggests that two or more disulphide bonds were present in the antimicrobial domain, ${ }^{[38]}$ thus inferring that protein folding was maintained. The same result was reported on previous studies with silk fusion proteins. ${ }^{[19,39]}$

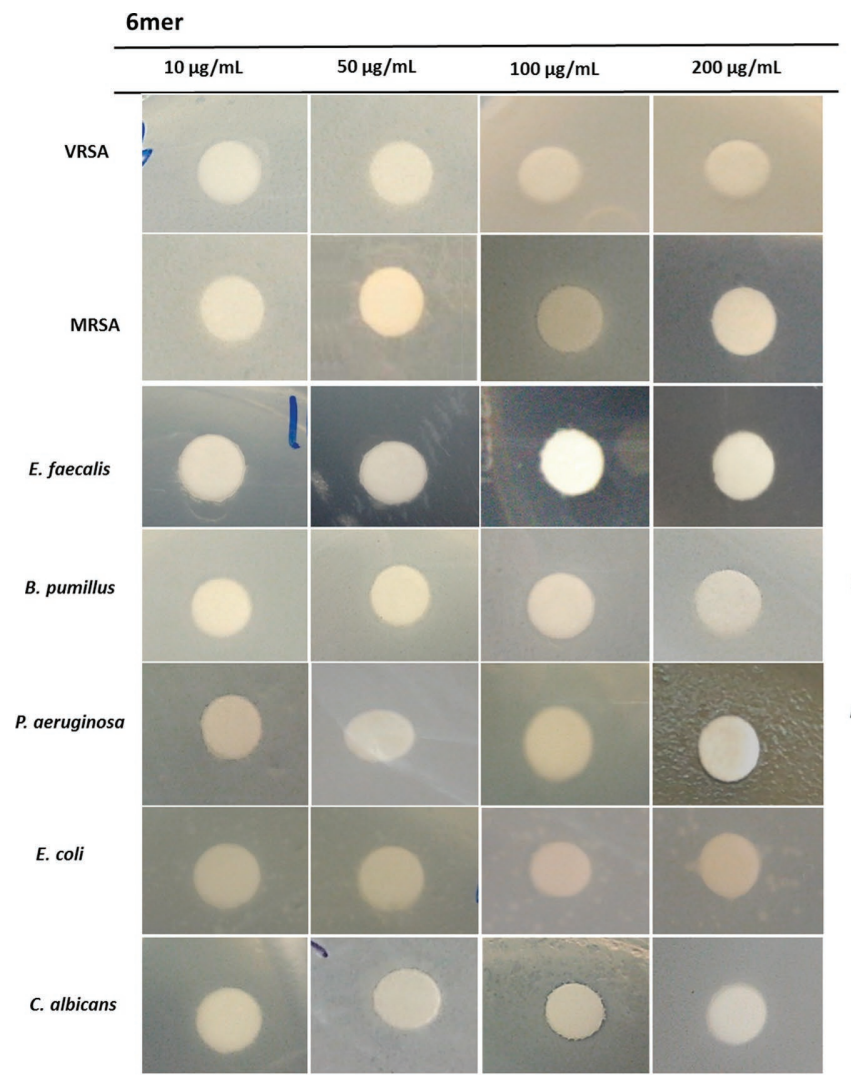

Also in the 15 mer fusion protein (Figure $2 \mathrm{E}$ ), the presence of a negative elasticity with a minimum of $200 \mathrm{~nm}$ suggested a random coil configuration, with a negative shoulder at $220 \mathrm{~nm}$, thus indicating the presence of additional structures like $\alpha$-helix or $\beta$-sheet. ${ }^{[40]}$ However, in the 15 mer proteins with the antimicrobial peptides, $15 \mathrm{mer}-\mathrm{Hep}$, and $15 \mathrm{mer}$ HNP1, a positive ellipticity with a maximum of 195-200 nm and a negative ellipticity with a minimum of $210 \mathrm{~nm}$ was detected (Figure 2E). These results suggest that the insertion of the antimicrobial peptides may have caused protein conformation to change, possibly due to the formation of disulfide linkage.

\subsection{Antimicrobial Activity of the Bioengineered Spider Silk Proteins}

The antimicrobial activity of the bioengineered spider silk proteins was assessed against VRSA, MRSA, E. feacalis, B. pumillus, E. coli, $P$. aeruginosa, and $C$. albicans using the radial diffusion assay (Figure 3 and S1, Supporting Information; Table 1).

In the present study, 6mer-HNP1 protein showed higher bacterial activity against Gram+ bacteria (i.e., MRSA) than to Grambacteria (e.g., P. aeruginosa) at a range of concentration (10 to $200 \mu \mathrm{g} \mathrm{mL} \mathrm{m}^{-1}$ ) (Figure 3; Table 1). For the other bioengineered proteins, a microbial inhibitory effect was only observed at the highest concentrations tested $\left(100-200 \mu \mathrm{g} \mathrm{mL} \mathrm{m}^{-1}\right)$.

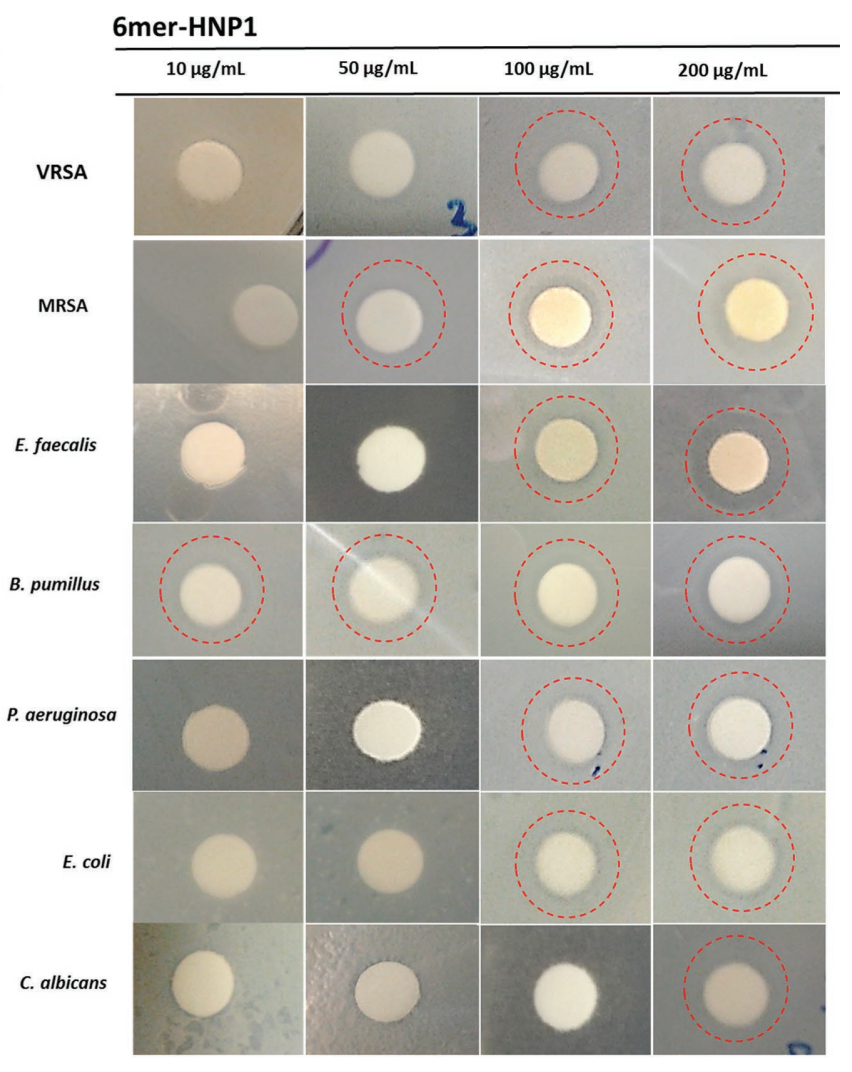

Figure 3. Representative image of the antimicrobial activity of 6 mer and 6 mer-HNP1 bioengineered proteins against VRSA, MRSA, E. feacalis, $B$. pumillus, P. aeruginosa, E. coli, and C. albicans, using radial diffusion assay. Protein concentrations were 10, 50, 100, and $200 \mu \mathrm{g} \mathrm{mL} \mathrm{L}^{-1}$. Proteins $6 \mathrm{mer}$ and $15 \mathrm{mer}$ were used as controls. Blank disks (Oxoid) with $8 \mathrm{~mm}$ were used. Red dash-line indicates the formation of the zone of growth inhibition. 
Table 1. Evaluation of the antimicrobial activity of the bioengineered spider silk proteins with antimicrobial peptides against microbial pathogens.

\begin{tabular}{|c|c|c|c|c|c|c|c|}
\hline \multirow[t]{2}{*}{ Microorganisms } & \multirow[t]{2}{*}{ Concentration $\left[\mu \mathrm{g} \mathrm{mL}^{-1}\right]$} & \multicolumn{6}{|c|}{ Diameter of the inhibition zone $[\mathrm{mm}]$} \\
\hline & & $6 \mathrm{mer}$ & 6mer-Hep & 6mer-HNP1 & $15 \mathrm{mer}$ & 15 mer-Hep & 15mer-HNP1 \\
\hline \multirow[t]{4}{*}{ VRSA } & 10 & 0 & 0 & 0 & 0 & 0 & 0 \\
\hline & 50 & 0 & 0 & 0 & 0 & 0 & 0 \\
\hline & 100 & 0 & 0 & 2 & 0 & 0 & 0 \\
\hline & 200 & 0 & 2 & 2 & 0 & 1 & 2 \\
\hline \multirow[t]{4}{*}{ MRSA } & 10 & 0 & 0 & 0 & 0 & 0 & 0 \\
\hline & 50 & 0 & 0 & 2 & 0 & 0 & 0 \\
\hline & 100 & 0 & 0 & 3 & 0 & 0 & 0 \\
\hline & 200 & 0 & 0 & 4 & 0 & 0 & 0 \\
\hline \multirow[t]{4}{*}{ E. faecalis } & 10 & 0 & 0 & 0 & 0 & 0 & 0 \\
\hline & 50 & 0 & 0 & 0 & 0 & 0 & 0 \\
\hline & 100 & 0 & 0 & 2 & 0 & 0 & 0 \\
\hline & 200 & 0 & 0 & 5 & 0 & 0 & 0 \\
\hline \multirow[t]{4}{*}{ B. pumillus } & 10 & 0 & 0 & 2 & 0 & 0 & 0 \\
\hline & 50 & 0 & 0 & 2 & 0 & 0 & 0 \\
\hline & 100 & 0 & 0 & 2 & 0 & 0 & 0 \\
\hline & 200 & 0 & 3 & 3 & 0 & 1 & 2 \\
\hline \multirow[t]{4}{*}{ P. aeruginosa } & 10 & 0 & 0 & 0 & 0 & 0 & 0 \\
\hline & 50 & 0 & 0 & 0 & 0 & 0 & 0 \\
\hline & 100 & 0 & 0 & 2 & 0 & 0 & 0 \\
\hline & 200 & 0 & 0 & 4 & 0 & 0 & 0 \\
\hline \multirow[t]{4}{*}{ E. coli } & 10 & 0 & 0 & 0 & 0 & 0 & 0 \\
\hline & 50 & 0 & 0 & 0 & 0 & 0 & 0 \\
\hline & 100 & 0 & 0 & 1 & 0 & 0 & 0 \\
\hline & 200 & 0 & 0 & 2 & 0 & 0 & 0 \\
\hline \multirow[t]{4}{*}{ C. albicans } & 10 & 0 & 0 & 0 & 0 & 0 & 0 \\
\hline & 50 & 0 & 0 & 0 & 0 & 0 & 0 \\
\hline & 100 & 0 & 0 & 0 & 0 & 0 & 0 \\
\hline & 200 & 0 & 3 & 3 & 0 & 1 & 2 \\
\hline
\end{tabular}

The antimicrobial activity of HNP1 varied when fused with different spider silk domains. 15mer-HNP1 only showed antimicrobial activity against VRSA, B. pumillus, and C. albicans growth at the concentration of $200 \mu \mathrm{g} \mathrm{mL} \mathrm{mL}^{-1}$ (Figure S1, Supporting Information; Table 1). Further analysis of antimicrobial activity of the bioengineered proteins was carried out in liquid LB medium (Figure S2, Supporting Information). An inhibitory growth effect of 6mer-HNP1 protein was observed against MRSA, VRSA, E. feacalis, B. pumillus, E. coli, P. aeruginosa, and $C$. albicans, corroborating the our earlier findings that this protein has broad antimicrobial activity. The shift in protein conformation of the bioengineered protein $15 \mathrm{mer}$ HNP1 could have resulted in reduced antimicrobial activity compared to 6mer-HNP1 protein, suggesting that the antimicrobial activity of HNP1 varied when fused with different spider silk domains. Also, while the secondary structure of the bioengineered proteins remained similar in the 6 mer proteins, the CD data (Figure 2E) showed that the protein configuration of 6 mer and 15 mer proteins changed due to the formation of disulfide bonds, suggesting that protein folding may have inter- fered with the antimicrobial potential of Hep and HNP1. ${ }^{[41,42]}$ The 6mer-Hep and 15mer-Hep proteins also demonstrated the same inhibiting effect on VRSA, B. pumillus, and C. albicans at higher concentration $\left(200 \mu \mathrm{g} \mathrm{mL} \mathrm{m}^{-1}\right)$ as $15 \mathrm{mer}-\mathrm{HNP} 1$ (Figure S1, Supporting Information; Table 1). Hep antibacterial activity has been linked to stabilization of the 3D structure provided by the intramolecular disulfide bridges bonds, whereas in HNP1, the order of connectivity between the three disulphide bonds does not impair HNP1 peptide antimicrobial activity. ${ }^{[38]}$ Nevertheless, the results from our study suggest that by fusion with 6 mer or 15 mer spider silk motifs, the antimicrobial activity was lower when compared to the 6 mer-HNP1 protein activity. This may be due to protein folding, making the antimicrobial peptide site less available and thus less bioactive.

In the present study, only 6mer-HNP1 had broad antimicrobial activity against the tested microorganisms. The other proteins with Hep (6mer-Hep and 15mer-hep) and HNP1 (15mer-HNP1) showed antimicrobial activity against specific microorganisms. HNP1 peptides are known to be more prone to kill S. aureus (Gram+ bacteria) than against Gram- bacteria 
as well as virus and fungi. ${ }^{[1]}$ The mechanism of action has not been completely identified, although previous studies suggested that the antimicrobial potential could be due to binding to membrane precursor lipid II present on cell membranes and leading to membrane permeability as well as inhibiting metabolic process. ${ }^{[42,43]}$ 6mer-HNP1 also inhibited the growth of $E$. coli and $P$. aeruginosa, but at a higher concentrations (Figure 3, Table 1), further corroborating our finding that Gram+ bacteria are more susceptible to 6 mer-HNP1 peptides. Nevertheless, it is not clear how these bioengineered spider silk proteins affect bacteria and further investigation is needed to clarify this issue.

Also, in the present study, the protein 6 mer-Hep only showed antimicrobial activity against VRSA and C. albicans (Figure 3, Table 1), suggesting that the antimicrobial potential of this protein could be dependent of the microorganism strain tested. Gomes et al. ${ }^{[19]}$ reported that the functionalization of spider silk domain 6 mer with Hepcidin demonstrated an inhibitory effect against Gram- bacteria rather than Gram+. Hep was previously described to have antibacterial activity. This is a natural human host defense peptide known to act as an iron regulatory hormone, and to have a broad spectrum of antimicrobial activity against E. coli, S. epidermidis, S. aureus, and group B streptococci, as well as fungi. ${ }^{[4,45]}$

\subsection{Aggregation and Charge of the Bioengineered Proteins}

Another factor that can interfere with the antimicrobial activity of the bioengineered proteins is the formation of aggregates and the protein surface charge. ${ }^{[19]}$ DLS analysis was used to assess the aggregation of 6mer-Hep, 6mer-HNP1, 15mer-Hep, and 15 mer-HNP1 proteins, since the assembly state could impact antimicrobial activity (Figure 4).

Results showed that the increase of particle diameter of the 6mer, 6mer-Hep, 6mer-HNP1, 15mer, 15mer-Hep, and 15merHNP1 was dependent of concentration (Figure 4). The presence of the spider silk domains can explain this behavior, since silk proteins are known to self-assemble in solution with increased concentration. ${ }^{[19]}$ Of the 6 mer and 15 mer proteins functionalized either with Hep or HNP1 peptides, two different particle sizes were detected. The proteins 6 mer-Hepcidn and $15 \mathrm{mer}$ Hepcidin showed a smaller particle size when compared to the silk-alone proteins 6 mer or 15 mer, whereas the 6 mer-HNP1 and 15mer-HNP1 showed an increase in size. Protein aggregation increased at higher concentrations, which can affect antimicrobial capacity interfering with protein surface charges as well as with the proper folding of the bioengineered proteins, rendering them less active against pathogens.

These results could be explained by the presence of the different antimicrobial domains, resulting in a variation of assembled sizes, influencing the number of charged amino acids. Therefore, the surface charge of the bioengineered proteins was evaluated with the same concentrations as used for the antimicrobial tests (Table 2).

The protein 6 mer showed a neutral zeta potential at the lowest concentrations tested, becoming relatively negatively charged at concentrations of $50-200 \mu \mathrm{g} \mathrm{mL}^{-1}$. As for the $15 \mathrm{mer}$, it showed a relative negative charge on all tested concentrations. As for the 6mer-Hep, the protein surface showed a nega- tive surface charge at the different concentrations tested (10$200 \mu \mathrm{g} \mathrm{mL} \mathrm{m}^{-1}$ ), while $6 \mathrm{mer}-\mathrm{HNP} 1$ protein presented a positive surface charge through all the concentrations tested. The same positively charged trend was also observed with the protein surface of 15 mer-Hep at the tested concentrations. The protein 15mer-HNP1 presented a positive charge at $10-50 \mu \mathrm{g} \mathrm{mL} \mathrm{L}^{-1}$, which shifted to a negative charged surface at higher concentrations (100-200 $\mu \mathrm{g} \mathrm{mL}^{-1}$ ) (Table 2).

The protein 6 mer showed a neutral zeta potential at the lowest concentrations tested, becoming relatively negative-charged at concentrations $50-200 \mu \mathrm{g} \mathrm{mL} \mathrm{mL}^{-1}$. As for the protein $15 \mathrm{mer}$, it showed a relative negative-charged surface protein on all tested concentrations. As for 6 mer-Hep, the protein surface showed an induced negative surface charge at the different concentrations tested (10-200 $\mu \mathrm{g} \mathrm{mL}^{-1}$ ), while 6mer-HNP1 protein presented a positive surface charge through all the concentrations tested. The same positively charged trend was also observed with the protein surface of 15mer-Hep at the tested concentrations. The protein 15mer-HNP1 presented a positive charge at concentrations $10-50 \mu \mathrm{g} \mathrm{mL} \mathrm{L}^{-1}$, which shifted to a negatively charged surface at higher concentrations $\left(100-200 \mu \mathrm{g} \mathrm{mL} L^{-1}\right.$ ) (Table 2). These results suggest that the presence of the antimicrobial peptides in the spider silk domain block could have an impact on protein surface charge, possibly due to the reorganization of the exposed monomers at the protein surface. The presence of the different antimicrobial domains can increased or decreased the number of charged amino acids at the surface, resulting in a variation of protein size and charged. In fact, positively charged surface attract negatively charged bacterial cells, while negativecharged surfaces repel such cells, ${ }^{[46]}$ which can affect the antimicrobial properties of the bioengineered proteins. Also, the integrity of the microbial cell wall can become compromised by the adsorption of such positive-charged peptides. ${ }^{[46]}$ In the present study, only the bioengineered protein 6mer-HNP1 demonstrated a broad antimicrobial activity against the several bacteria and a fungus, while the other proteins (6mer-Hep, 15mer-Hep, and 15mer-HNP1) showed a less inhibitory effect on tested pathogens, possibly due to a decrease on function property of the bioengineered proteins.

\subsection{Multifunctional Silk-Based Films with Antimicrobial Properties}

Since there is an urgent need to develop biomaterials capable of impeding SSI by preventing adherence and biofilm formation by microbial pathogens, ${ }^{[8]}$ multifunctional silk-based films with antimicrobial properties were generated by combining 6merHNP1 protein with a broad antimicrobial activity as mentioned above, with different contents of SF (10\%, 12\%, and 15\%). By engineering novel polymers with intrinsic antimicrobial or anti-infective properties, new and smarter biomaterials can be developed. In the present study, SF was chosen as a backbone structure in order to develop multifunctional films, since this natural protein polymer has outstanding properties and has been widely used to produce different types of biomaterials from films to fibers and other variants. ${ }^{[12]}$

The secondary structure of the silk-based films was assessed by ATR-FTIR (Figure 5A), where an increase in $\beta$-sheet content 
$6 \mathrm{mer}$

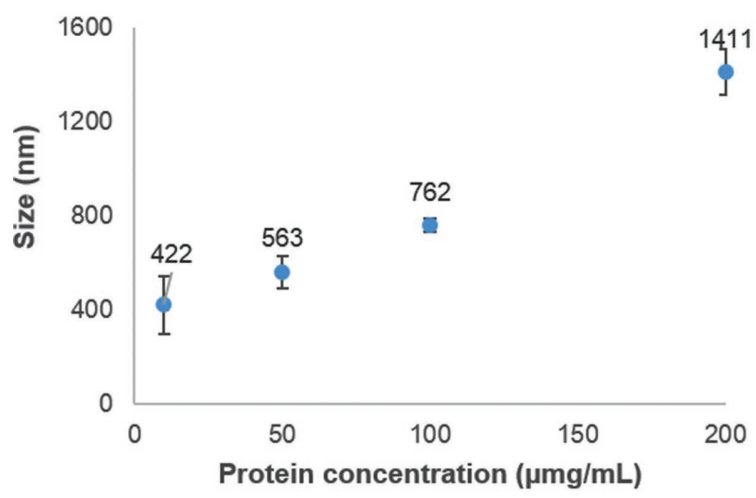

6mer-Hep

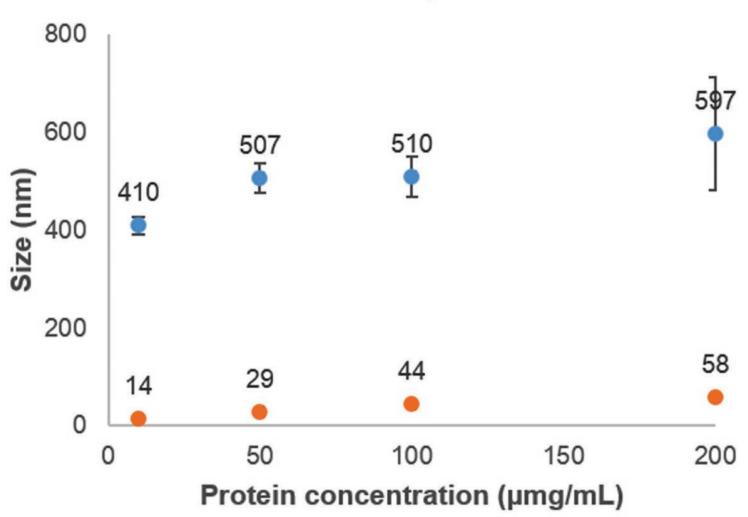

6mer-HNP1

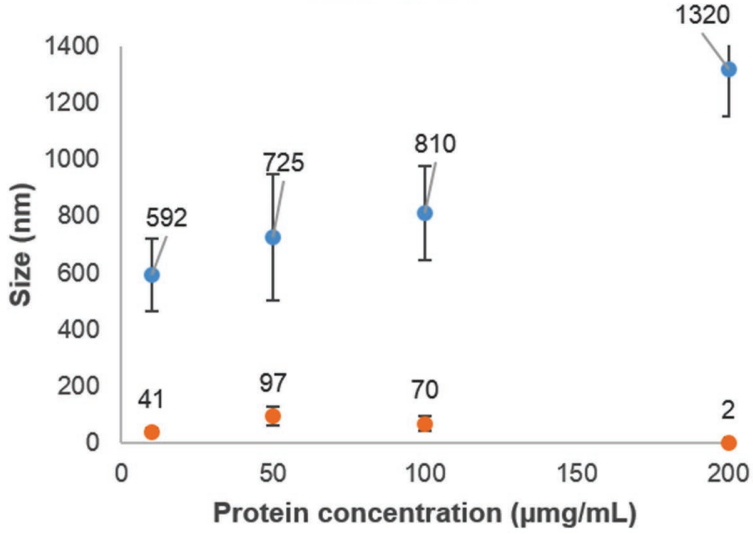

15mer

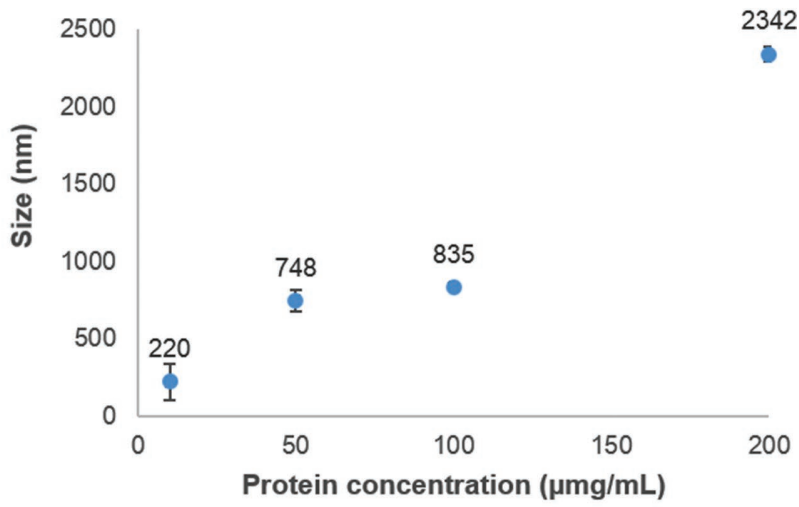

15mer-Hep

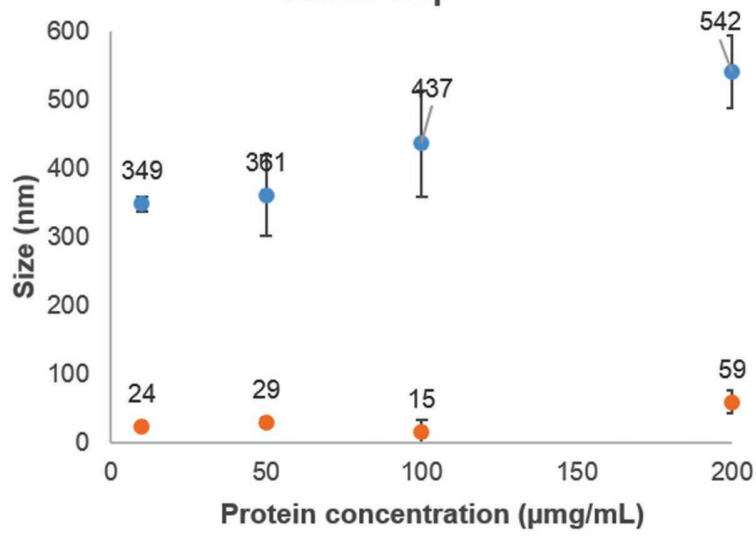

15mer-HNP1

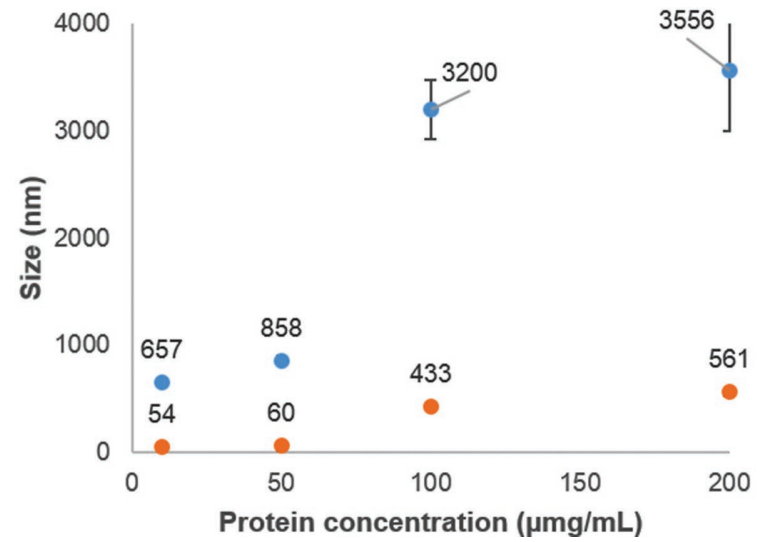

Figure 4. DLS measures of particle diameter $(\mathrm{nm})$ as a function of protein concentration. Blue dots correspond to particles diameters from the aggregation of high charge molecules, whereas orange dots correspond to particles diameters from the aggregation of lower charge molecules.

in the amide I and amide II regions after methanol treatment was found. On all films, the average percentage for the secondary structures, mainly $\beta$-sheet content, was calculated through the integration of the area of each deconvoluted curve, normalizing the obtained value to the total area of the amide I and amide II regions. Spectra deconvolution revealed the decrease of helix/ random coil conformations and increase of antiparallel $\beta$-sheet structures on all the developed films after methanol treatment (Figure 5A), as expected. These results suggest that the combina- tion of SF with the bioengineered spider silk protein does not interfere with the formation of antiparallel $\beta$-sheet.

One of the most important parameters that can influence microbial adhesion and biofilm formation is related to the surface of medical devices. ${ }^{[47]}$ Herein, we assessed the surface morphology and topography of the multifunctional silk-based films by SEM and AFM (Figure 5B,C). In the SEM micrographs of the silk films containing only SF (10\%, $12 \%$, and $15 \%$ SF), it was possible to detect the presence of small aggregates from silk 
Table 2. Zeta potential of the bioengineered spider silk proteins in $\mathrm{H}_{2} \mathrm{O}$ at $25^{\circ} \mathrm{C}$.

\begin{tabular}{lrrrr}
\hline Bioengineered spider silk protein & \multicolumn{4}{c}{ Protein concentration $\left[\mu \mathrm{m} \mathrm{mL}^{-1}\right]$} \\
\cline { 2 - 5 } & \multicolumn{1}{c}{10} & 50 & \multicolumn{1}{c}{100} & 200 \\
\hline 6 mer & $0.14 \pm 3.14$ & $-9.69 \pm 4.40$ & $-2.30 \pm 0.74$ & $-1.05 \pm 0.512$ \\
6 mer-Hep & $-1.31 \pm 0.26$ & $-3.74 \pm 2.54$ & $-3.49 \pm 0.37$ & $-10.9 \pm 1.50$ \\
6 mer-HNP1 & $4.79 \pm 0.35$ & $5.04 \pm 0.21$ & $8.95 \pm 0.88$ & $6.09 \pm 0.23$ \\
15 mer & $-1.43 \pm 1.35$ & $1.49 \pm 0.24$ & $-1.16 \pm 0.37$ & $-1.43 \pm 0.17$ \\
15 mer-Hep & $3.29 \pm 0.22$ & $9.83 \pm 0.37$ & $14.5 \pm 0.25$ & $9.85 \pm 0.46$ \\
15 mer-HNP1 & $9.25 \pm 0.24$ & $6.98 \pm 0.63$ & $-3.72 \pm 1.05$ & $-1.74 \pm 0.63$ \\
\hline
\end{tabular}

materials at the films surface (Figure 5B). As for the silk-based films containing 6 mer or 6mer-HNP1, the surface morphology was homogenous, with the exception of the films containing $15 \% \mathrm{SF}$ and 6mer-HNP1, where some aggregates were also detected (Figure 5B). As for the AFM topographic images, the silk-based films with the bioengineered proteins (6mer or 6merHNP1) presented a smoother surface when compared to the SF alone surface (Figure 5B and Table 3).

The control films made with only different SF contents showed the formation of aggregates at the film surface (Figure 5B). The surface roughness values RMS and RA (calculated from the height images) of the silk films made with
$10-12 \% \mathrm{SF}$ and the bioengineered spider proteins, 6mer and 6mer-HNP1 were significantly $(p<0.05)$ lower than the control films with only $10-12 \%$ SF. Also, the silk-based films prepared with 6mer or 6mer-HNP1 showed a similar smoother surface (Table 3). These results suggest that the presence of the proteins 6mer or 6mer-HNP1 have higher surface smoothness than the SF films. However, the same trend was not observed in the $15 \%$ silk-based films containing 6mer, 6mer-HNP1, or SF alone, where the roughness values RMS and Ra values showed no significant differences $(p>0.05)$. Nevertheless, the enhanced roughness surface values in these films could be related to an increase of silk fibrils due to the higher content in silk (15\%).
A
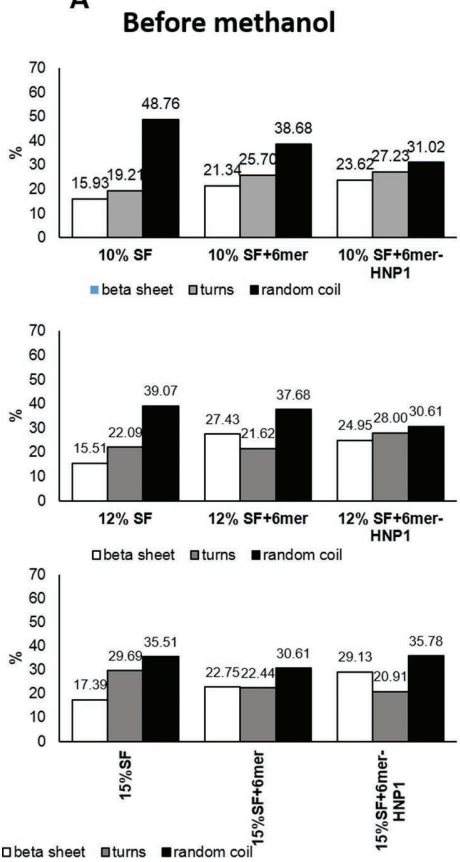

After methanol
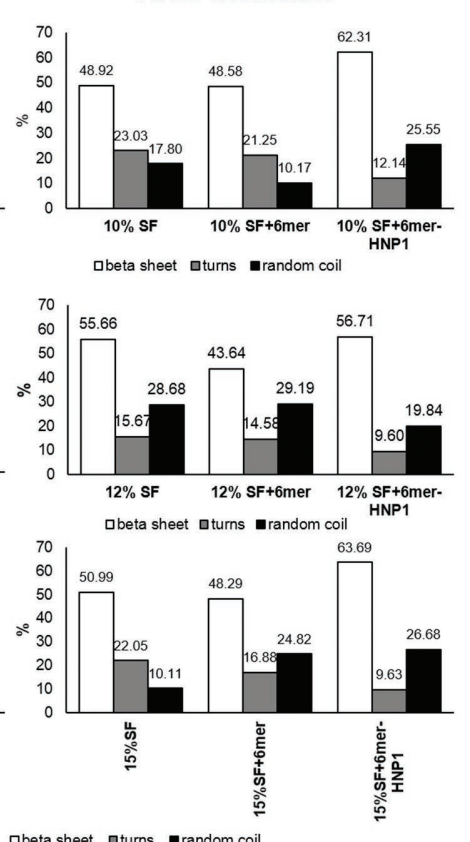

B
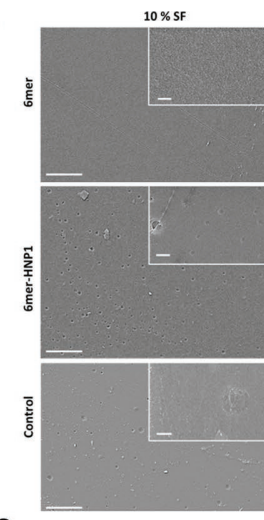

C

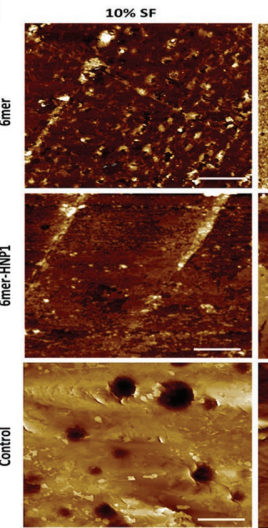

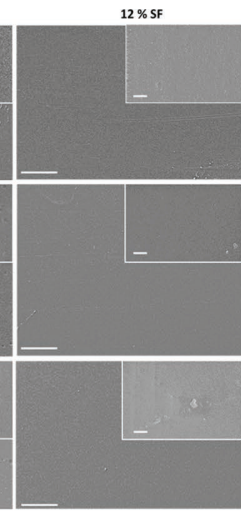

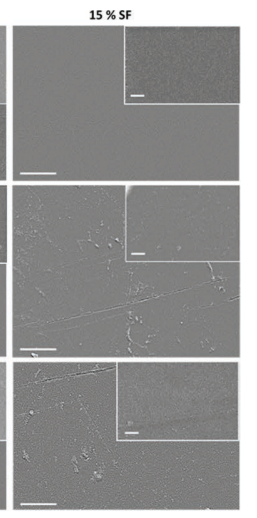

$12 \% \mathrm{SF}$
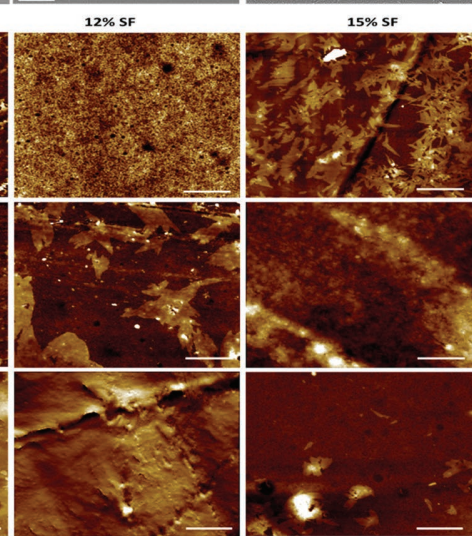

Figure 5. Characterization of the silk-based films made with $10 \% \mathrm{SF}+2 \% 6 \mathrm{mer}, 12 \% \mathrm{SF}+2 \% 6 \mathrm{mer}, 15 \% \mathrm{SF}+6 \mathrm{mer}, 10 \% \mathrm{SF}+2 \% 6 \mathrm{mer}-\mathrm{HNP1}, 12 \%$ $\mathrm{SF}+2 \% 6 \mathrm{mer}-\mathrm{HNP1}, 15 \% \mathrm{SF}+6$ mer-HNP1. Films prepared with only $10 \%, 12 \%$, and $15 \%$ SF were used as controls. A) Percentage of $\beta$-sheet, turns and random coil/helix conformations after ATR-FTIR spectra deconvolution of the silk-based films. Spectra conformation were assessed before and after methanol treatment; B) SEM micrographs of multifunctional silk-based films with $10 \%, 12 \%$ and $15 \%$ SF combined with 6 mer or 6 mer-HNP1 proteins. The scale bar corresponds to $10 \mu \mathrm{m}$ in the main image and $1 \mu \mathrm{m}$ in the insets; C) AFM topographies of multifunctional silk-based films. The scale bar corresponds to $1 \mu \mathrm{m}$. 
Table 3. Surface Roughness, RMS, and Ra for the multifunctional films.

\begin{tabular}{|c|c|c|c|}
\hline Film & & Rms [nm] & $\mathrm{Ra}[\mathrm{nm}]$ \\
\hline \multirow[t]{3}{*}{$10 \% \mathrm{SF}$} & SF only & $22.6 \pm 2.82 \mathrm{a}$ & $14.9 \pm 1.24 \mathrm{a}$ \\
\hline & 6 mer & $5.95 \pm 0.62 b$ & $4.17 \pm 0.20 b$ \\
\hline & 6mer-HNP1 & $5.14 \pm 1.39 b$ & $3.32 \pm 0.69 b$ \\
\hline \multirow[t]{3}{*}{$12 \%$ SF } & SF only & $16.0 \pm 3.07 \mathrm{a}$ & $12.5 \pm 2.36 \mathrm{a}$ \\
\hline & $6 \mathrm{mer}$ & $3.47 \pm 0.84 b$ & $2.56 \pm 0.61 b$ \\
\hline & 6mer-HNP1 & $4.81 \pm 0.52 b$ & $3.46 \pm 0.18 b$ \\
\hline \multirow[t]{3}{*}{$15 \%$ SF } & SF only & $18.0 \pm 12.2 \mathrm{a}$ & $9.91 \pm 6.90 \mathrm{a}$ \\
\hline & 6 mer & $12.0 \pm 2.77 \mathrm{a}$ & $8.82 \pm 2.03 a$ \\
\hline & 6mer-HNP1 & $7.08 \pm 0.69 a$ & $5.13 \pm 0.58 \mathrm{a}$ \\
\hline
\end{tabular}

Rms: root mean square; Ra: arithmetic average height. Means \pm SD with different letters in the same column differed significantly according to Tukey's Multiple Range test at $p<0.05$

\subsection{Bacterial Viability and Adherence to the Multifunctional Silk-Based Films}

As mentioned earlier, the prevention of bacterial infections by reducing bacteria adherence or inactivation is one of the strategies that needs to be further investigated. ${ }^{[47]}$ Since lower surface roughness could influence cell adherence as well as bacterial adherence, the viability and adherence of MRSA on the surface of the silk-based films was investigated after $24 \mathrm{~h}$ growth (Figure 6).

The silk-based films with 6mer and 6mer-HNP1 proteins showed significantly lower bacteria viability when compared to the films with SF alone (Figure 6A,B). In the silk-based films with 6mer or 6mer-HNP1, bacterial viability was similar
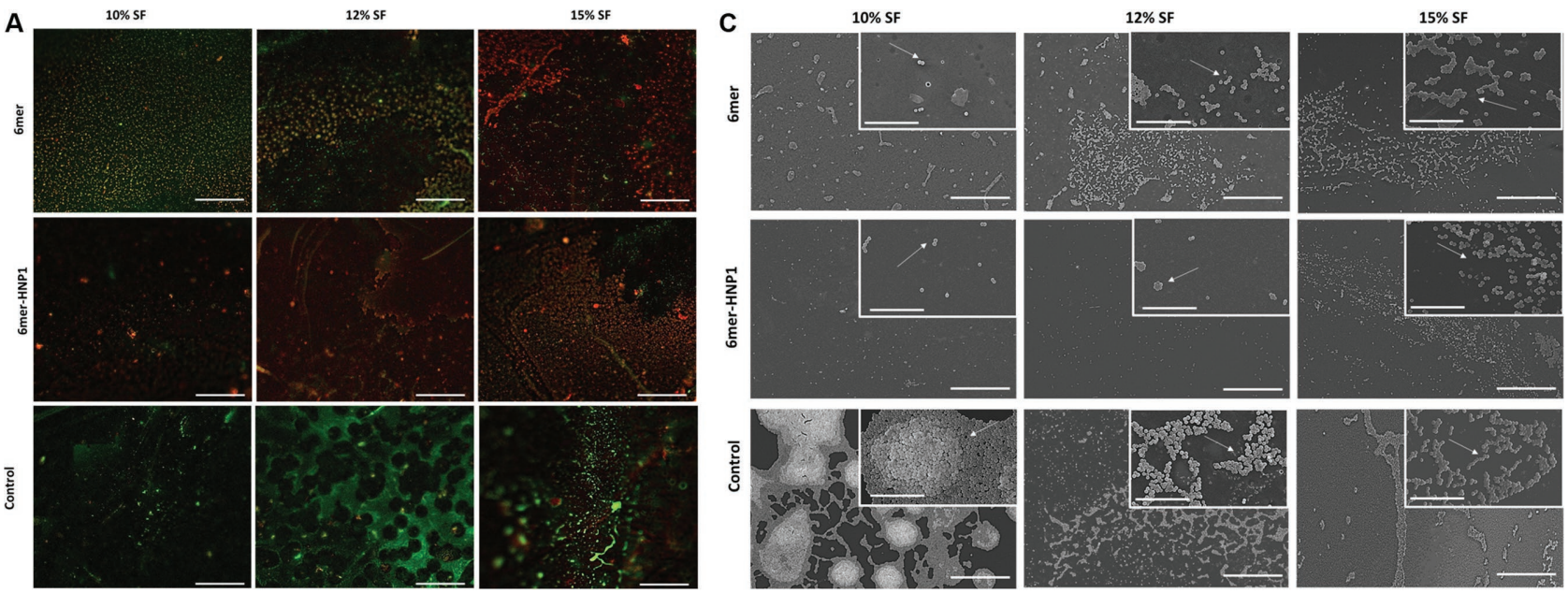

B

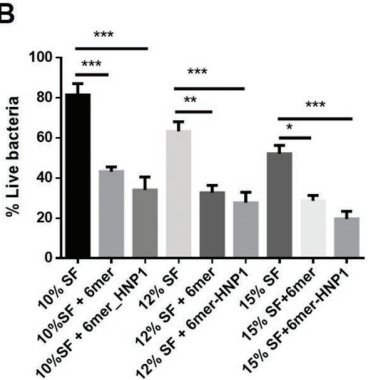

Figure 6. MRSA viability on the silk-based films made with $10 \% \mathrm{SF}+2 \% 6 \mathrm{mer}, 12 \% \mathrm{SF}+2 \% 6 \mathrm{mer}, 15 \% \mathrm{SF}+6 \mathrm{mer}, 10 \% \mathrm{SF}+2 \% 6 \mathrm{mer}-\mathrm{HNP1}, 12 \%$ $\mathrm{SF}+2 \% 6$ mer-HNP1, $15 \% \mathrm{SF}+6$ mer-HNP1. Films prepared with only $10 \%, 12 \%$, and $15 \% \mathrm{SF}$ were used as controls. A) Representative images of MRSA adherence and biofilm formation. Live bacteria were stained green using SYTO 9 and Dead bacteria were stained red using PI. The scale bar correspond to $50 \mu \mathrm{m}$; B) Percentage of viability of MRSA after $24 \mathrm{~h}$ at $37^{\circ} \mathrm{C}$; C) SEM micrographs showing the formation of biofilm and bacterial adherence of MRSA on the silk-based films after $24 \mathrm{~h}$ at $37^{\circ} \mathrm{C}$. White arrows point bacteria adhesion. The scale bar corresponds to $50 \mu \mathrm{m}$ in the main image and $10 \mu \mathrm{m}$ in the insets. 
(Figure 6B). The formation of a bacterial biofilm on the films containing only SF $(10 \%, 12 \%$, and $15 \%)$ was observed by SEM after $24 \mathrm{~h}$ of incubation (Figure 6C). The films containing $6 \mathrm{mer}$ and 6mer-HNP1 proteins supported less bacterial adherence, the $10 \%$ and $12 \%$ SF films made with 6 mer-HNP1 were lower than those with 6mer (Figure 6C). Also, no biofilm formation was observed on these films with the exception of films containing 15\% SF and 6mer-HNP1 (Figure 6C).

These multifunctional silk-based films functionalized with the bioengineered 6mer-HNP1 significantly decreased the adherence and proliferation of MRSA, as well as the formation of biofilms when compared to films prepared with SF alone or functionalized with 6 mer protein (Figure 6). This effect could be attributed to the antimicrobial potential of the functionalized spider silk protein 6mer-HNP1. Moreover, higher surface roughness can result in more bacteria adherence, leading to the formation of biofilms and SSI. ${ }^{[48]}$ In the present study, the surface roughness of the multifunctional silk films with the bioengineered proteins was significant lower $(p<0.05)$ than in the silk films with only SF. These results could explain the reduction in adherence and proliferation of Gram+ bacteria on the films with the bioengineered proteins. Also, this can translate to a reduction of risk of infection. Furthermore, lower viable counts of MRSA were observed on films with 6mer-HNP1 when compared to the films with 6mer, suggesting that 6merHNP1 offers an advantage for utility for new antimicrobial biomaterials.

\subsection{Cytotoxicity of the Multifunctional Silk-Based Films}

The cytotoxic response to the silk-based films was evaluated using human foreskin fibroblasts (HFF) (Figure 7).

DNA content was quantified to evaluate cell proliferation (Figure 7A). An increase in DNA content was observed over time in culture, indicating cell proliferation. However, after 7 days of growth, the amount of DNA was lower in the silk-based films when compared to the positive controls (Plastic) without any

A

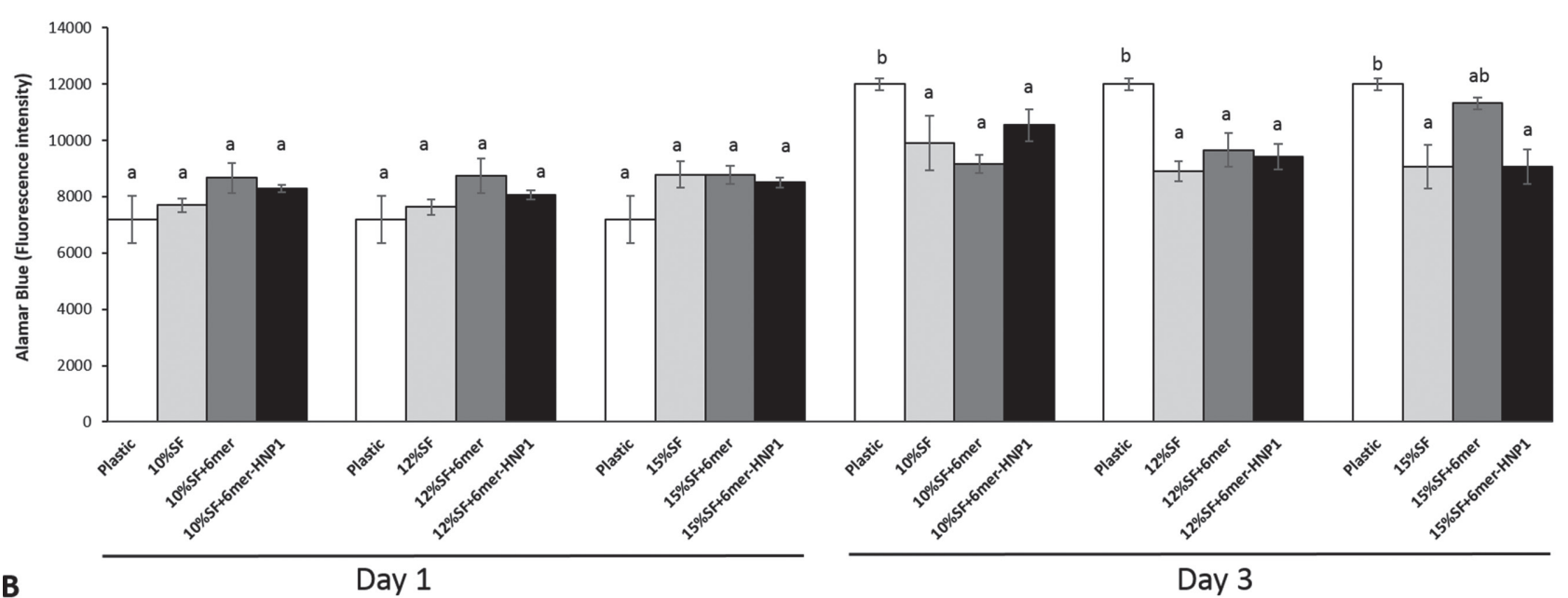

B

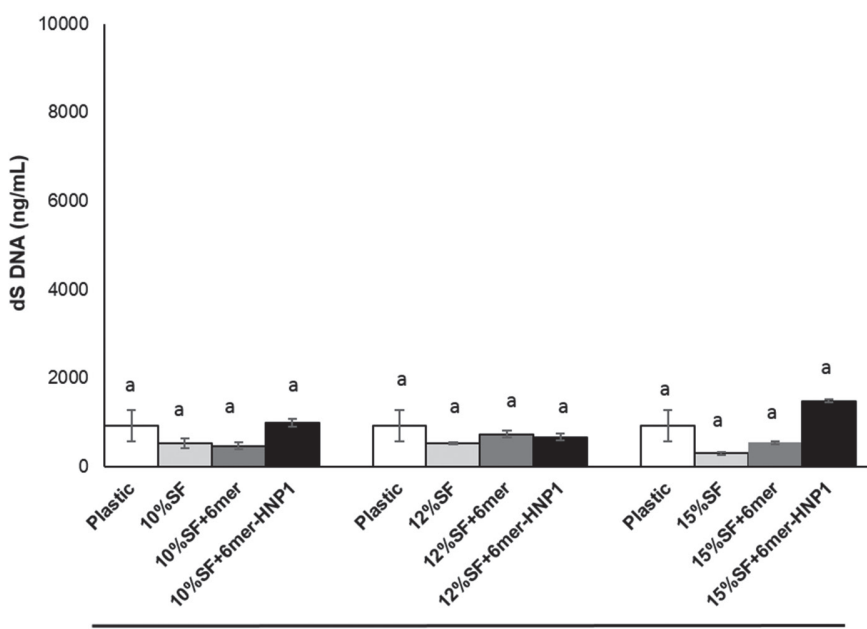

Day 1

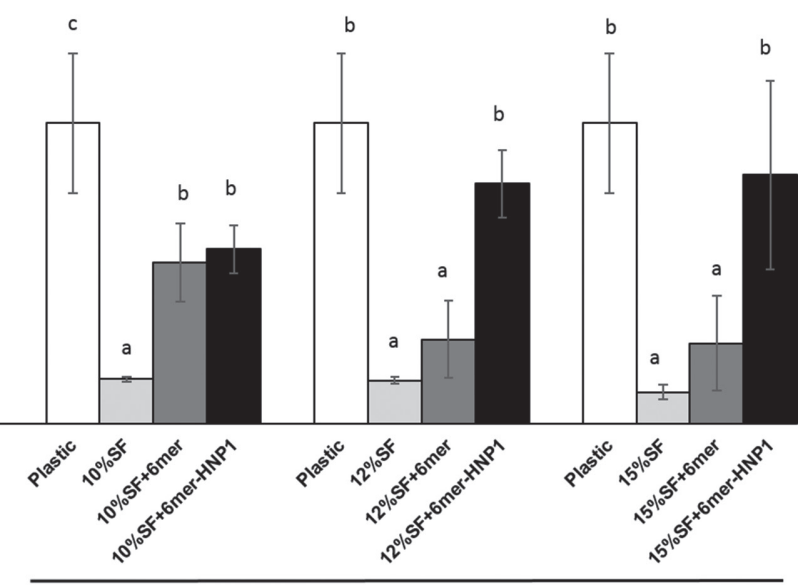

Day 3

Figure 7. A) Cellular viability/proliferation (Alamar Blue assay) and B) Double strand DNA (dsDNA) quantification assay of HFFs cultured on the multifunctional silk-based films after 1 and 3 days in DMEM medium. Plastic stands for tissue culture plastic, used as a positive control. Columns with different letters differed significantly according to Tukey Multiple Range test at $p<0.05$. 
silk-based films. The metabolic activity of HFF showed no significant differences when grown on the different films (Figure 7B). These results demonstrate that the increase in SF content in the presence of the bioengineered proteins 6mer and 6mer-HNP1 were still able to support mammalian cell proliferation.

The response of HFF to the multifunctional silk films showed no significant effect (Figure 7), indicating that these multifunctional silk-based films containing 6mer or 6merHNP1 supported mammalian cell adhesion and proliferation. These results, together with the antimicrobial properties of the multifunctional silk films, suggest that it is possible to tailor novel biomaterials to prevent biofilm formation, without impairing mammalian cell growth and proliferation.

In summary, the outcomes of this study indicate that 6mer-HNP1 in combination with SF-generated new, drugfree polymers, tailored to reduce microbial adhesion and biofilm formation, without impairing mammalian cell growth and proliferation. These materials pose advantageous alternatives for medical devices to prevent or reduce SSI, without the extensive use of antibiotics. ${ }^{[8]}$ Nevertheless, it is necessary to further investigate the requisites of how these new antimicrobial biomaterials respond to infection in a clinical setting.

\section{Conclusion}

The present study investigates the potential of using multifunctional silk films with bioengineered spider silk proteins fused with antimicrobial peptides to prevent SSI. Through recombinant DNA technology, it was possible to design and specifically tailor new spider silk materials for this task. These new bioengineered proteins retained native spider silk properties, mainly the formation of $\beta$-sheet, which confers exceptional mechanical properties, and also, the antimicrobial activity of the fused peptides. When combined with SF, the protein 6 merHNP1 prevented the adherence and formation of bacterial biofilms. Further, bacterial viability on the films with 6mer-HNP1 was significantly reduced compare with SF films alone or combined with 6 mer. Moreover, the proliferation of HFFs was also sustained on the films, suggesting these new materials as intriguing candidates for new drug-free polymers with antimicrobial properties. In fact, the importance of this investigation relies on the ability to engineer smart materials able to prevent biofilm formation while supporting cellular proliferation. It is necessary to further expand this investigation to determine mechanistically how these multifunctional silk materials affect the formation of bacterial biofilms, including the effect on Gram+ bacteria, thus preventing SSI.

\section{Supporting Information}

Supporting Information is available from the Wiley Online Library or from the author.

\section{Acknowledgements}

The Portuguese Foundation for Science and Technology (FCT) under the project PTDC/BBB-BIO/0827/2012 and by the European
Regional Development Fund (FEDER) through the "COMPETE" Operational Programme for Competitiveness factors (FCOMP-01-0124FEDER-028120) supported this work. The authors would like to thank Prof. Celia Manaia from the Escola Superior de Biotecnologia (Porto, Portugal) for providing the Pseudomonas sp. bacteria; and Dr. Alberta Faustino from the Hospital de S. Marcos (Braga, Portugal) for providing the other bacterial strains. A. R. Franco thanks FCT through the PostDoctoral scholarship SFRH/BPD/100760/2014

\section{Conflict of Interest}

The authors declare no conflict of interest.

\section{Keywords}

antimicrobial peptides, bacterial adhesion, biocompatibility, bioengineered silk proteins, drug-free polymers

Received: July 11, 2018

Revised: October 3, 2018

Published online:

[1] V. Gopalakrishnan, M. Kim, G. An, Adv. Wound Care 2013, 2, 510.

[2] M. Renko, N. Paalanne, T. Tapiainen, M. Hinkkainen, T. Pokka, S. Kinnula, J. J. Sinikumpu, M. Uhari, W. Serlo, Lancet Infect. Dis. 2017, 17, 50.

[3] S. Berkner, S. Konradi, J. Schönfeld, EMBO Rep. 2014, 15, 740.

[4] Y. Fan, Z. Wei, W. Wang, L. Tan, H. Jiang, L. Tian, Y. Cao, S. Nie, Sci. Rep. 2015, 4, 6783.

[5] P. W. Stone, Expert Rev. Pharmacoeconomics \& Outcomes Res. 2009, 9, 417.

[6] S. C. Mellinghoff, J. J. Vehreschild, B. J. Liss, O. A. Cornely, J. Med. Internet Res. 2018, 20, e1.

[7] D. M. Tsai, E. J. Caterson, Patient Saf. Surg. 2014, 8, 42.

[8] C. R. Arciola, D. Campoccia, L. Montanaro, Nat. Rev. Microbiol. 2018, 16, 397

[9] X. Khoo, M. W. Grinstaff, MRS Bull. 2011, 36, 357.

[10] A. Francesko, K. Ivanova, J. Hoyo, S. Pérez-Rafael, P. Petkova, M. M. Fernandes, T. Heinze, E. Mendoza, T. Tzanov, Biomacromolecules 2018, 19, 3628 .

[11] T. Yucel, M. L. Lovett, D. L. Kaplan, J. Controlled Release 2014, 190, 381.

[12] N. Hassani Besheli, F. Mottaghitalab, M. Eslami, M. Gholami, S. C. Kundu, D. L. Kaplan, M. Farokhi, ACS Appl. Mater. Interfaces 2017, 9, 5128.

[13] Y. Qian, F. Qi, Q. Chen, Q. Zhang, Z. Qiao, S. Zhang, T. Wei, Q. Yu, S. Yu, Z. Mao, C. Gao, Y. Ding, Y. Cheng, C. Jin, H. Xie, R. Liu, ACS Appl. Mater. Interfaces 2018, 10, 15395.

[14] A. P. Gomes, J. F. Mano, J. A. Queiroz, I. C. Gouveia, Polym. Adv. Technol. 2013, 24, 1005.

[15] M. M. Umair, Z. Jiang, N. Ullah, W. Safdar, Z. Xie, X. Ren, J. Ind. Text. 2016, 46, 59.

[16] J. G. Hardy, A. Leal-Egaña, T. R. Scheibel, Macromol. Biosci. 2013, 13, 1431.

[17] T. B. Aigner, E. DeSimone, T. Scheibel, Adv. Mater. 2018, 30, 1704636

[18] O. Tokareva, V. a. Michalczechen-Lacerda, E. L. Rech, D. L. Kaplan, Microb. Biotechnol. 2013, 6, 651.

[19] S. C. Gomes, I. B. Leonor, J. F. Mano, R. L. Reis, D. L. Kaplan, Biomaterials 2011, 32, 4255.

[20] N. Dinjaski, D. Ebrahimi, S. Ling, S. Shah, M. J. Buehler, D. L. Kaplan, ACS Biomater. Sci. Eng. 2017, 3, 2877. 
[21] Z. Zhou, S. Zhang, Y. Cao, B. Marelli, X. Xia, T. H. Tao, Adv. Mater. 2018, 30, 1 .

[22] S. Lin, S. Ryu, O. Tokareva, G. Gronau, M. M. Jacobsen, W. Huang, D. J. Rizzo, D. Li, C. Staii, N. M. Pugno, J. Y. Wong, D. L. Kaplan, M. J. Buehler, Nat. Commun. 2015, 6, 6892.

[23] L. Sanchez-Garcia, L. Martín, R. Mangues, N. Ferrer-Miralles, E. Vázquez, A. Villaverde, Microb. Cell Fact. 2016, 15, 1.

[24] N. Ferrer-Miralles, J. Domingo-Espín, J. Corchero, E. Vázquez, A. Villaverde, Microb. Cell Fact. 2009, 8, 17.

[25] S. Costa, A. Almeida, A. Castro, L. Domingues, Front. Microb. 2014, $5,1$.

[26] C. H. Bowen, B. Dai, C. J. Sargent, W. Bai, P. Ladiwala, H. Feng, W. Huang, D. L. Kaplan, J. M. Galazka, F. Zhang, Biomacromolecules 2018, 19, 3853.

[27] A. M. Pereira, R. Machado, A. da Costa, A. Ribeiro, T. Collins, A. C. Gomes, I. B. Leonor, D. L. Kaplan, R. L. Reis, M. Casal, Acta Biomater. 2017, 47, 50.

[28] J. Zhao, H. Qiu, D. Chen, W. Zhang, D. Zhang, M. Li, Int. J. Biol. Macromol. 2013, 56, 106.

[29] S. Gomes, J. Gallego-Llamas, I. B. Leonor, J. F. Mano, R. L. Reis, D. L. Kaplan, J. Tissue Eng. Regener. Med. 2012, 6, 356.

[30] S. Gomes, J. Gallego-Llamas, I. B. Leonor, J. F. Mano, R. L. Reis, D. L. Kaplan, Macromol. Biosci. 2013, 13, 444.

[31] O. S. Rabotyagova, P. Cebe, D. L. Kaplan, Biomacromolecules 2009, 10, 229.

[32] X. Hu, D. Kaplan, P. Cebe, Macromolecules 2006, 39, 6161.

[33] D. N. Rockwood, R. C. Preda, T. Yücel, X. Wang, M. L. Lovett, D. L. Kaplan, Nat. Protoc. 2011, 6, 1612.

[34] P. Cacciafesta, K. Hallam, A. Watkinson, G. Allen, M. Miles, K. Jandt, Surf. Sci. 2001, 491, 405.
[35] E. Gadelmawla, M. Koura, T. Maksoud, I. Elewa, H. Soliman, J. Mater. Process. Technol. 2002, 123, 133.

[36] X. Ding, S. Duan, X. Ding, R. Liu, F.-J. Xu, Adv. Funct. Mater. 2018, 28, 1802140.

[37] S. Zhou, W. Huang, D. J. Belton, L. O. Simmons, C. C. Perry, X. Wang, D. L. Kaplan, Acta Biomater. 2015, 15, 173.

[38] J. Varkey, R. Nagaraj, Antimicrob. Agents Chemother. 2005, 49, 4561.

[39] R. Jansson, N. Thatikonda, D. Lindberg, A. Rising, J. Johansson, P. Å. Nygren, M. Hedhammar, Biomacromolecules 2014, 15, 1696.

[40] E. Bini, C. W. P. Foo, J. Huang, V. Karageorgiou, B. Kitchel, D. L. Kaplan, Biomacromolecules 2006, 7, 3139.

[41] E. H. Mattar, H. A. Almehdar, H. A. Yacoub, V. N. Uversky, E. M. Redwan, Cytokine Growth Factor Rev. 2016, 28, 95.

[42] G. Wei, E. de Leeuw, M. Pazgier, W. Yuan, G. Zou, J. Wang, B. Ericksen, W. Y. Lu, R. I. Lehrer, W. Lu, J. Biol. Chem. 2009, 284, 29180.

[43] E. de Leeuw, C. Li, P. Zeng, C. Li, M. D. de Buin, W. Y. Lu, E. Breukink, W. Lu, FEBS Lett. 2010, 584, 1543.

[44] P. Strnad, P. Schwarz, M. C. D. Rasenack, O. Kucukoglu, R. I. Habib, D. Heuberger, R. Ehehalt, M. W. Müller, A. Stieh, G. Adler, H. Kulaksiz, PLoS One 2011, 6, e16454.

[45] F. Alcayaga-Miranda, J. Cuenca, M. Khoury, Front. Immunol. 2017, $8,1$.

[46] J. P. da Costa, M. Cova, R. Ferreira, R. Vitorino, Appl. Microbiol. Biotechnol. 2015, 99, 2023

[47] M. M. Konai, B. Bhattacharjee, S. Ghosh, J. Haldar, Biomacromolecules 2018, 19, 1888.

[48] M. Canty, N. Luke-Marshall, A. Campagnari, M. Ehrensberger, Acta Biomater. 2017, 48, 451. 